School of Finance

University of St.Gallen

THE IMPACT OF REgUlATORY STRESS TESTING ON BANK'S EQUITY AND CDS PERFORMANCE

Lukas Ahnert, PAscal Vogt, Volker Vonhoff, AND FLORIAN WEIGERT

SWISS INSTITUTE OF BANKING AND FINANCE (S/BF - HSG)

MAY 2018 


\title{
The Impact of Regulatory Stress Testing on Bank's Equity and CDS Performance
}

\author{
Lukas Ahnert, Pascal Vogt, Volker Vonhoff, and Florian Weigert*
}

This Version: May, 2018

\begin{abstract}
This paper investigates the impact of stress testing results on bank's equity and CDS performance using a large sample of ten tests from the US CCAR and the European EBA regimes in the time period between 2010 and 2017. We find that passing banks experience positive abnormal equity returns and tighter CDS spreads, while failing banks show strong drops in equity prices and widening CDS spreads. Interestingly, we also document strong market reactions at the announcement date of the stress tests. A bank's asset quality and its return on equity at the time of the announcement are significant predictors of the pass/fail outcome of a bank.
\end{abstract}

Keywords: Banks, Stress Testing, Equity Performance, CDS Performance

JEL Classification Numbers: G00, G21, G28

*Lukas Ahnert is from the University of St. Gallen, Unterer Graben 21, 9000 St. Gallen, Switzerland. Email: lukas.ahnert@student.unisg.ch. Pascal Vogt is from the Boston Consulting Group, Cologne, Germany. Email: vogt.pascal@bcg.com. Volker Vonhoff is from the Boston Consulting Group, New York, USA. Email: vonhoff.volker@bcg.com. Florian Weigert is from the University of St. Gallen, Swiss Institute of Banking and Finance, Unterer Graben 21, 9000 St. Gallen, Switzerland. Email: florian.weigert@unisg.ch. Tel: +41-71-224-7014. 


\title{
The Impact of Regulatory Stress Testing on Bank's Equity and CDS Performance
}

\author{
This Version: May, 2018
}

\begin{abstract}
This paper investigates the impact of stress testing results on bank's equity and CDS performance using a large sample of ten tests from the US CCAR and the European EBA regimes in the time period between 2010 and 2017. We find that passing banks experience positive abnormal equity returns and tighter CDS spreads, while failing banks show strong drops in equity prices and widening CDS spreads. Interestingly, we also document strong market reactions at the announcement date of the stress tests. A bank's asset quality and its return on equity at the time of the announcement are significant predictors of the pass/fail outcome of a bank.
\end{abstract}

Keywords: Banks, Stress Testing, Equity Performance, CDS Performance

JEL Classification Numbers: G00, G21, G28 


\section{Introduction}

Over the scope of little more than a decade, bank stress tests have developed into a key supervisory tool that shapes headlines and fundamentally affects the main business operations of banks worldwide. The financial crisis of 2008-09 revealed that capital on bank balance sheets was insufficient - both in quantity and quality - to withstand large adverse shocks. Hence, following the crisis, regulators pushed for tighter rules and a systemic overhaul of the pre-crisis Basel II framework with a key focus on the refinement of bank capital. The post-crisis adjustments of these capital standards continue to present a challenge for financial institutions, especially in times of overall low bank profitability and crisis legacy costs. To assess if banks are keeping pace with regulatory demands, supervisors around the globe increasingly rely on stress testing.

Bank stress tests are analyses conducted under simulated unfavourable economic scenarios to assess the capitalization of banks on a forward-looking basis. They focus on several key risks, such as credit risk, market risk, and liquidity risk, to determine the banks' financial health in crisis situations. Stress tests break with traditional supervisory approaches in their far-reaching disclosures and provide market participants with unprecedented insights into bank balance sheets. Moreover, at the same time, stress tests place follow-up requirements on banks that fall short of supervisory expectations.

The aim of this paper is to further develop the understanding of the impact of stress testing on banks' equity and CDS performance. We apply the abnormal return (AR) event study design to assess a sample of the ten most recent tests of the US CCAR and the European EBA regimes in the time period from 2010 to 2017. To the best of our knowledge, this presents the largest cross-jurisdictional sample analysed up-to-date. Following previous work in this field, we analyze short-term performance implications around stress test release and announcement events. Hence, this study provides new insights to the field of financial regulation as well as expands and updates findings of the existing literature. ${ }^{1}$

For stress test result release events, this study identifies significant abnormal equity and CDS returns for tested banks. Passing banks, on aggregate, experience significantly positive abnormal equity returns of 59 basis points and significantly tighter CDS spreads of -83 basis points. To the contrary, failing banks earn significantly negative abnormal equity returns of 206 basis points and widening CDS spreads of 172 basis points. Taken together, we observe that the overall effect of stress tests is performance positive: On average, tested banks experience significantly positive abnormal equity returns of 36 basis points and significantly tighter CDS spreads of -72 basis points at the result release day.

\footnotetext{
${ }^{1}$ For a recent overview on employed data samples and results of the existing literature on stress testing, see Appendix A.1.
} 
For stress test announcement events, we observe a different picture and reveal capital market effects that are in the opposite direction to the result release events. Specifically, banks that are announced to be stress tested, earn significantly negative abnormal equity returns of 18 basis points and significantly wider CDS spreads of 78 basis points. Hence, the overall positive effect of stress tests on bank's equity and CDS spreads on the result release day can be seen as a compensation for negative effects realized on the stress test announcement day. Moreover, when combining the release and the announcement to a joint stress test effect, we do not find a statistically significant impact on the equity and CDS performance of US and European banks.

Finally, our study investigates whether bank fundamentals at the announcement event are able to forecast the final stress test outcome with corresponding abnormal equity and CDS performance. For this purpose, we perform a multivariate regression analysis of a bank's stress test release outcomes on a number of different bank characteristics measured at the time of the announcement date. We show that a bank's asset quality and its return of equity are significant predictors of the pass/fail outcome of a bank. Moreover, our results reveal that banks with a higher capital buffer, higher asset quality, lower leverage, and a less risky business model earn higher abnormal equity returns at the stress test release. Hence, the outcomes of stress test results are (at least partly) predictable at its announcement and it is likely that banks optimize their capital structure changes accordingly. In line with this idea, we find that banks which fail stress tests, improve their regulatory capital ratios through new capital issues over the 180 -days before the result release day. ${ }^{2}$

Together, our findings contribute to three areas of the academic stress test literature. First, we contribute to a growing number of studies that provide empirically-orientated impact assessments of the effectiveness of EBA and CCAR stress tests. Predominately, existing studies focus on analysing and comparing stress test implications either across years or across jurisdictions. Findings vary by tests studied and methodology applied. For the US, Morgan, Peristiani and Savino (2014) and Flannery, Hirtle and Kovner (2015) find that bank equity and CDS performance is significantly affected by stress test releases. Neretina, Sahin, and De Haan (2014) analyze US tests between 2009 and 2015 and show that significant implications cannot be found for all of these stress tests. However, they confirm a benign environment for bank CDS spreads after release dates. Georgescu, Gross, Kapp and Kok (2017) assess the 2014 and 2016 EBA tests for European banks and confirm the marketmoving impact of stress tests. They argue that stress tests allow for improved discrimination between banks. Empirical evidence for the impact of stress test announcements and predictability of stress test results remains scarce. Ellahie (2012) does not find significant

\footnotetext{
2 A possible interpretation of this empirical finding is that failing banks anticipate their stress test failure and issue new capital before the release day to mitigate their loss from declining equity prices and widening credit spreads.
} 
evidence that equity and CDS performance are associated to stress test announcements. Barucci, Baviera and Milani (2018) identify a relevant role of bank fundamentals, including capitalisation and non-performing exposures to predict test outcomes. Flannery et al. (2015) identify performance implications that increase in bank leverage. Morgan et al. (2014), as well as, Carboni, Fiordelisi, Ricci and Lopes (2017) document a relationship between announcement returns and result performance. They find that bank security performance around the release is predominately driven by the unexpected capitalization results of banks. We contribute to this literature by analyzing the impact of stress testing results and announcements in the up-to-date largest sample covering ten tests of the US CCAR and the European EBA regimes in the time period from 2010 to 2017.

Second, results of empirical assessments have implications for the discussion and design of optimal stress test disclosures. Banks are generally agreed to suffer from a strong degree of opaqueness - the inaccessibility of dependable financial data to outsiders. Market reaction to stress test releases is then argued to prove the existence and consequent reduction of opaqueness. However, one should consider that scale and timing of test information provision are contested as a trade-off between restoring confidence in passing institutions and singling-out failing institutions at the risk of destabilising the financial system (Goldstein and Leitner, 2015). Hence, studies that evaluate the market impact of stress test releases and announcements (such as ours) can be used to assess the modification of stress test designs (e.g., as for recent changes to EBA disclosures and reduced overall test transparency).

Third, a narrow field of literature has emerged around the wider implications of stress testing on bank conduct. Goldstein and Sapra (2014) identify the risk that banks engage in stress test management. At the same time, stress tests can incentivize the negligence of other risks not directly covered in the stress test. In their empirical analysis, Flannery et al. (2015), however, do not find evidence of these distortionary impacts. Our findings on increased capital issuances of failing banks before stress test releases contribute to this area of literature.

The remainder of this paper is structured as follows. Section 2 introduces the dataset and the event study methodology. Section 3 describes the relationship between stress test releases as well as equity and CDS performance. Section 4 expands this analysis to announcement dates. Section 5 identifies the link between underlying bank determinants and stress test results. Section 6 concludes. 


\section{Dataset and methodology}

\subsection{Stress tests}

We cover all ten important stress tests conducted in the US and Europe in the time period from 2010 to 2017. Key features of these stress tests are provided in Table 1. For each stress test, we report the announcement date, the release date, the competent authority, the number of banks tested, the number of banks failed, the hurdle rate, the regulatory followup, and the stress test scenarios. ${ }^{3}$ In addition, we provide an overview of the detailed timeline of all stress tests in the US and Europe in Figure 1.

[Insert Table 1 and Figure 1 around here]

For US stress tests, this study follows the existing literature by focusing on the US CCAR which is the relevant stress test for the largest banks with balance sheet volumes above $\$ 50 \mathrm{bn}$. The CCAR features both a qualitative and a quantitative element, either of which a bank can fail. The quantitative CCAR provides information on forecasted capital positions. The qualitative CCAR verifies bank internal capital planning processes and governance. Over the sample analyzed, the number of tested banks with tradable equity/or CDS ranges from 18 to 34 per stress test. We observe a total of 15 stress test failures of which nine are qualitative and six are quantitative failures.

For European stress tests, this study considers the 2010 and 2011 stress tests by the Committee of European Banking Supervisors as well as the 2014 and 2016 stress tests conducted by the European Bank Authority (EBA). These four stress tests will hereon be referred to as EBA stress tests. In contrast to CCAR, EBA tests have focused on quantitative outcomes alone. ${ }^{4}$ We report a number of 42 up to 79 banks per stress test with tradable equity and/or CDS. Out of these tested banks, 20 instances of EBA stress test failure have occurred.

Our overall sample consists of the union of all banks that are assessed in at least one of the stress tests. For CCAR stress tests, a total of 35 different banks with equity and/or CDS market data over the 2012-17 period are identified. ${ }^{5}$ For EBA stress tests, we report a total of 90 different banks with corresponding equity and/or CDS market data. Since our CDS

\footnotetext{
${ }^{3}$ For a description of the general stress testing methodology that underlies the US (CCAR) stress tests and the European (EBA) stress tests, we refer the reader to Appendix A.2.

4 Recent shifts in the stress testing methodology of EBA tests have and will further align EBA and CCAR, as the European supervisor attributes more weight to qualitative and bank-specific assessments.

${ }^{5}$ If banks are not listed themselves, they are attributed to their ultimate parent. Hence, foreign domiciled CCAR participants (e.g. Deutsche Bank Trust, Santander Holdings) are attributed the equity and CDS performance of their parents.
} 
database provider SNL Financial only provides five years of historical data, no CDS spreads are available for the 2010 and 2011 EBA as well as the 2012 CCAR stress tests.

A bank that is tested in selected individual stress tests only, is attributed to the peer group of non-tested banks in the remaining stress tests. Furthermore, CCAR and EBA peer groups are expanded with the 'next-20' listed US banks and the 'next-30' listed banks within the European Economic Area, respectively, based on average 2010-16 balance sheet sizes. ${ }^{6}$ As a result, approximately half of the abnormal equity return estimates (see Section 2.2) are computed for the stress-tested banks and half for the non-tested banks. For the CDS return study, approximately two-thirds of the observations belong to the stress-tested banks and one-third to the non-tested sample.

\subsection{Equity and CDS performance event study}

This paper employs the event study methodology pioneered by Fama, Fisher, Jensen and Roll (1969) and MacKinlay (1997) to compute abnormal return estimates which has become the standard approach in the stress test literature. The event study setup is illustrated along the four steps (i) to (iv) traditionally involved in event studies. We provide summary statistics in (v).

(i) Defining events

This study considers the day of stress test disclosure by the supervisor as the key event. Since results are published upon market closing, the event date is the next available trading day and around this day the abnormal security performance is analyzed. In a second step, this paper expands its analysis to the stress test announcement date - the first communication of supervisors to the public in a stress testing cycle. ${ }^{7}$

(ii) Estimating normal returns

We obtain daily per-bank equity prices from Reuters Datastream and CDS spreads (5 yearsenior) from the S\&P's SNL Financial Database. The estimation of normal returns follows the recent stress test literature and applies a one-factor market model according to Sharpe (1964). First, security prices are transformed into logarithmic returns using

$$
R_{i, t}=\ln \left(\frac{p_{i, t}}{p_{i, t-1}}\right)
$$

\footnotetext{
${ }^{6}$ Since balance sheet size is the key criteria on which stress tested banks are selected, any kind of peer group analysis is undermined by the fact that stress-test and peer group allocation is not random.

7 Some ambiguity exists in the literature regarding the classification of the announcement event. We follow recent central bank working papers by relying on the date on which the first stress test related press release is made available by a supervisor. This press release typically reveals the set of tested banks and gives details on the applied stress test methodology.
} 
where $R_{i, t}$ is the $\log$ return and $p_{i, t}$ is the end-of-day market closing price for day $t$ of security $i$. This approach is applied to both equity prices as well as CDS spreads. It follows the work of Flannery et al. (2015) and Morgan et al. (2014) who also analyze CDS spreads as a logarithmic return series. Since CDS spreads are quoted in basis points and are increasing in riskiness, their interpretation is opposite to that of equity performance. A reduction in CDS spreads is referred to as 'spread tightening'. Vice versa, an increase in CDS spreads is referred to as 'spread widening'.

Second, an estimation window of 120-trading days that ends 10 trading days before the event $(-10,-130)$ is constructed. ${ }^{8}$ The exclusion of the last 10 trading days should shield the estimation against event related drifts. The parameters $\alpha$ and $\beta$ of the one-factor model are then estimated over the estimation window using

$$
R_{i t}=a_{i}+\beta_{i} R_{m, t}+\varepsilon_{i, t}
$$

In our main specification, we follow Morgan et al. (2014) and use a financial sector market model. For the equity market, we use the S\&P 500 Financials index for CCAR stress tests and the EURO STOXX Financials index for EBA stress tests. Moreover, for the CDS market, we apply the 5Y CDX North America Financials Senior index for CCAR stress tests and the 5Y iTraxx Europe Financials Senior index for EBA stress tests. All of our results are robust when we use a general (non-financial sector) market model (as in Candelon and Sy, 2015, and Petrella and Resti, 2013) or apply a hybrid model (i.e., a two-factor model including a country and a regional banking sector index, as in Georgescu et al., 2017).

(iii) Estimating abnormal returns

Abnormal returns $(A R)$ represent returns in excess of the estimated market model, computed as

$$
A R_{i t}=R_{i t}-\left(\widehat{a_{\imath}}+\hat{\beta}_{i} R_{m, t}\right)
$$

For the purpose of this study, $A R$ refers to $\mathrm{AR}_{\mathrm{it}=0}$, i.e., the abnormal return observable on the event day.

(iv) Estimating cumulative returns

In addition to the $A R$, a three-day cumulative abnormal return $(C A R)$ is applied in our analysis, which expands from the day before the event to the day after the event $(+1,-1)$ :

$$
C A R_{i}=\sum_{t=-1,0,+1} A R_{\mathrm{i} t}
$$

The CAR is the second key performance measure considered in this study.

\footnotetext{
8 Our results are robust when we apply a 250-trading days estimation window (as in Neretina et al., 2014) instead of a 120-trading days window.
} 
(v) Summary

Using the event study methodology as described above, we derive stress test-related abnormal equity and CDS return estimates across stress tests. For the equity event study, we compute 661 abnormal return estimates related to stress test release (and 657 for stress test announcement) events. Out of these 661 estimates, 306 are for retrieved for passing banks, 29 are for failing banks, and 326 for non-tested peer-group banks. For the CDS event study, we compute 186 abnormal return estimates: 149 for passing banks, 14 for failed banks, and 23 for non-tested peer-group banks. A detailed list of all banks participating in our stress test sample with corresponding available abnormal equity and CDS return estimates is reported in Appendix A.3. We use these estimates to assess the impact of stress test results and announcements on bank's equity and CDS performance in Section 3 and Section 4.

\section{Do stress test releases impact equity and CDS performance?}

Assessing performance differences over a sample of ten stress tests is appealing since the comparability of previous studies covering subsamples remains limited. This study starts with an analysis of abnormal equity and CDS performance associated with stress test releases. We analyze the performance of passing vs. failing banks in Section 3.1, and the performance of tested vs. non-tested banks in Section 3.2.

\subsection{Performance comparison: Passing vs. failing banks}

We start our empirical analysis by investigating the impact of stress test release outcomes (i.e., a pass or fail decision) on the impact of a bank's abnormal equity and CDS performance. Results are reported in Table 2.

[Insert Table 2 around here]

In line with the intuition that stress testing results provide important new information to market participants, we observe strong and significant effects on banks' equity and CDS prices. Passing banks, on aggregate, experience significantly positive abnormal equity returns of +59 basis points and significantly tighter CDS spreads of -83 basis points at the release date. We find that these patterns hold both for the US CCAR and the European EBA stress tests, i.e., passing banks in the CCAR (EBA) stress tests experience positive abnormal equity returns of $+64(+54)$ basis points and tighter CDS spreads of $-14(-138)$ basis points at the release date.

At the same time, we also observe that failure of stress tests is heavily penalized by market participants. Failing banks, on aggregate, show significantly negative abnormal equity returns of -206 basis points and significantly widening CDS spreads of +172 basis points at 
the release date. Similar patterns are observed both for the US CCAR and the European EBA stress tests: Failing banks in the CCAR (EBA) stress tests experience negative abnormal equity returns of $-204(-208)$ basis points and wider CDS spreads of $+234(+89)$ basis points at the release date. Our results are stable when we apply $C A R$ instead of $A R$ as our measure of abnormal bank performance.

On the individual stress test level, the aggregate findings are mostly confirmed. Equity market response to passes is positive in 9 of the 10 stress tests considered, of which 5 are statistically significant. ${ }^{9}$ The largest positive impact for passing banks is observed in the CCAR test in 2015 (+163 basis points) and the EBA test of 2010 (+114 basis points). For failing banks, our aggregate observation of negative equity returns and wider CDS spreads is also documented in all but one of the stress tests considered. We document the most severe negative equity and CDS market responses with regard to AR in the CCAR 2016 and EBA 2014 stress tests.

\subsection{Performance comparison: Tested vs. non-tested banks}

The existing literature does not give a clear picture on the impact of stress tests on the performance of tested banks. Candelon and Sy (2015) identify a positive impact of the 2009 and 2012 stress tests both in Europe and the US. Flannery et al. (2015) and Neretina et al. (2014) confirm this impact for the 2015 US CCAR stress test. To the contrary, Georgescu et al. (2017) find an overall marginally negative impact on participating banks. Hence, we now examine the impact of stress testing on the equity and CDS performance of tested banks and compare it to peer group performance.

Table 3 reports the results on the overall effect of stress test releases on bank's abnormal equity and CDS performance in the CCAR and EBA tests between 2010 and 2017.10

\section{[Insert Table 3 around here]}

Across all stress tests covered, we document that the overall effect of stress test releases is performance positive. On average, tested banks experience significantly positive abnormal equity returns of 36 basis points and significantly tighter CDS spreads of -72 basis points. These results are confirmed when we look at $C A R$ instead of $A R$ as our main measure of abnormal performance.

When we dig deeper, we find that the high-level results do not hold for all individual tests. For CCAR tests, equity ARs are negative in the 2014 and 2016 iterations with an average

\footnotetext{
${ }^{9}$ We only find one negative equity market response to passing banks in the case of the CCAR 2014 stress test and thereby confirm the finding of Neretina et al. (2014).

${ }^{10}$ Due to the low number of available CDS spreads we exclude empirical results for non-stress tested banks in the EBA 2016 sample.
} 
impact of -58 basis points and -8 basis points. We also do not find a significant impact on European banks' equity performance except from the EBA 2010 stress test, whose strong results are consistent with a 'novelty stress test effect'. On the CDS side, differences between EBA and CCAR appear substantial. EBA stress tests releases have resulted in a significant abnormal spread tightening of -142 basis points, while the direction of the impact is less clear for the banks in the CCAR sample.

The impact of stress testing on equity and CDS performance of tested banks is particularly positive in the CCAR 2017 test, which has, to the best of our knowledge, not been assessed in the existing literature up-to-date. This result does not confirm the empirical results of Glasserman and Tangirala (2015) who highlight the risk of diminishing information value of stress test results as they become a consistent feature of the supervisory agenda. Hence, the release of stress testing results delivers important information to market participant even in the sixth consecutive iteration of Fed annual stress testing. ${ }^{11}$

The examination of equity and CDS abnormal return magnitudes across Table 2 and Table 3 reveals another interesting observation: For the aggregate sample of tested banks, we show -- in Table 3 -- that the magnitude of the abnormal CDS return (-72 basis points), on average, is twice as large as the abnormal equity return (+36 basis points). The pass/fail split of Table 2 reveals that this observation is mostly driven by a stronger CDS ( -83 basis points) than equity (+59 basis points) response for passing banks. To the contrary, for failing banks, market reaction on banks' equity (-206 basis points) is more pronounced than on banks' CDS spreads (+172 basis points). Hence, the likelihood for passing a stress test appears to be more strongly incorporated in a bank's equity value than in its CDS spread. ${ }^{12}$

Finally, we also check whether stress-testing result releases also show significant spillover effects to non-tested banks (as noted by Flannery et al., 2015, for a group of selected US stress tests). In our large sample of ten stress tests both from the US and Europe, we do not observe a clear picture. We find, on average, that non-tested banks earn a positive (negative) equity return of $+19(-27)$ basis points when looking at the daily $A R$ (three-day CAR). In terms of CDS performance, we observe that non-tested banks show tighthening CDS spreads of -67 basis points ( -126 basis points) for the abnormal (cumulative abnormal)

\footnotetext{
11 While an in-depth analysis of stress test performance on a year-by-year basis is beyond the scope of this paper, our findings are in line with previous results in the literature. For example, as in Petrella and Resti (2013), we observe a muted and insignificant market response to the EBA 2011 stress test (abnormal equity return of only 11 basis points) which is reconciled with undermined EBA credibility following the 2010 assessment's inability to detect troubled Irish lending institutions.

12 Although these different pricing patterns are difficult to reconcile with the efficient market hypothesis, a possible explanation is that investors anticipate a bank's stress test failure and are insuring themselves on the credit market against the bank's financial collapse. Such a scenario would lead to increasing CDS spreads of a failing bank before the stress test release and a more muted response on the release day.
} 
performance. However, these numbers are not statistically significantly different from zero. Hence, we do not find clear evidence of consistent spillover effects from tested to non-tested financial institutions across our sample.

\section{Do stress test announcements impact equity and CDS performance?}

The previous section of this paper confirms a significant impact of stress test releases on a bank's equity and CDS performance. Do we also see an immediate market reaction solely based on the fact that a stress test for a bank is announced? We investigate this question in Section 4.1. Furthermore, we investigate the combined stress test impact, i.e., the market impact of the stress test release and the stress test announcement in Section 4.2.

\subsection{The role of stress test announcements: Tested vs. non-tested banks}

As already stated in Section 2.2, we define the first communication of supervisors to the public in a stress testing cycle as the stress test announcement event. This announcement typically takes place more than six months before the stress test release. Recent academic studies illustrate that, at the time of the stress test announcement, market participants are likely to form preliminary assessments of banks' expected equity and CDS stress test performance. As an example, Carboni et al. (2017) find that investors are able to identify weak banks with the announcement of the EBA 2014 stress test and Morgan et al. (2014) show that also the 2009 Fed SCAP, the CCAR's predecessor, results were, to a certain extent, anticipated. We follow these previous approaches and examine the relevance of the announcement event for the equity and CDS performance of banks. Results are reported in Table 4.

[Insert Table 4 around here]

We find that the average impact of stress test announcements is very different from the average impact of stress test results on banks' performance. While Table 3 displays that tested banks experience positive abnormal equity returns of 36 basis points and tighter CDS spreads of -72 basis points at the stress test result day, we observe -- in Table 4 -- that tested institutions experience negative abnormal equity returns of -18 basis points and wider CDS spreads of 78 basis points at the announcement day. Again, these results are robust when we apply the $C A R$ instead of the $A R$ as our main measure of abnormal performance.

As in the case of result releases, the announcement performance varies across stress tests. For banks' equity performance, we observe that the announcement effect leads to negative returns in four out of six cases in the US, and in two out of four cases in Europe. On the CDS 
side, we show that the overall widening CDS spreads are mainly due to the EBA stress test announcements and not due to the CCAR announcements.

Finally, we also look at spill-over effects between tested- and non-tested banks at the announcement day. As for the release day, we cannot document significant spillover effects from tested to non-tested financial institutions at the announcement day in our sample.

\subsection{Combining announcement and result events}

After having reported the different directions of the average stress test announcement and the stress test result effect, we now turn to investigate the combined effect in Table 5.

[Insert Table 5 around here]

We find that the joint impact of test announcement and release result cancels out and is close to zero for the equity and CDS performance of tested banks. Specifically, when taking account of both effects, tested banks experience positive equity returns of 18 basis points and wider CDS spreads of 6 basis points with t-statistics displaying values smaller than one are being far from statistically significant.

On the individual stress test level, we also document that stress test release and announcement effects point in opposite directions, especially in Europe. We observe -- for all European stress tests - that a positive (negative) announcement event performance is followed by a negative (positive) result event performance. We obtain slightly weaker, but qualitatively similar results also for US banks.

To summarize, we find that the overall positive effect of stress tests on bank's equity and CDS spreads on the result release day can be seen as a compensation for a negative effect realized on the stress test announcement day. Hence, the mostly positive market response to stress test releases predominately corrects a more negative initial expectation that develops at the time of stress test announcements.

\section{Can outcomes of a bank's stress test be predicted?}

Following the assessment of stress test performance around announcement and result events, we now further investigate the link between the two. In particular, we examine whether stress test outcomes (pass/fail) and associated financial market outcomes at the stress test release day can be predicted with bank fundamentals at the stress tests announcement date. ${ }^{13}$

\footnotetext{
13 This analysis adds an additional dimension to the existing literature. Barucci et al. (2018) identify various crosssectional fundamental drivers of stress test outcomes for the EBA 2014 stress test. They illustrate that
} 
Following the existing literature, we construct different fundamentals that give a holistic representation of the state of a bank. All measures are based on accounting data available at the time of the stress test announcement. EXCESS CAP is defined as the difference between bank regulatory capital ratio at the announcement event and minimum required capitalisation to pass the stress test and measures bank capitalization going into the stress test. ASSET QUALITY assesses overall balance sheet quality and is defined as the ratio of non-performing assets to regulatory capital (CET1). LEVERAGE is defined as the ratio of CET1 capital to total balance sheet size - hence, the measure corresponds to the leverage ratio supervisors employ. RWA/A captures the riskiness of business models, following the premise that riskier banks feature a higher RWA to asset density. ROAE measures the return on equity over the trailing 12-month period, a key determinant for bank internal capital generation. Finally, given the relation between announcement and result performance uncovered earlier, and the findings of Morgan et al. (2014), ANNOUNCEMENT AR is the abnormal equity market reaction at the announcement date of the stress test. All fundamental data is sourced from S\&P's SNL Financial database and collected at the time of the stress test announcement.

To predict the outcome of banks' stress tests and corresponding performance at the release day we perform different regression models in Table 6.

[Insert Table 6 around here]

Specification (1) reports the results of a logistic regression to assess the predictive power of the above-mentioned bank characteristics (EXCESS CAP, ASSET QUALITY, LEVERAGE, RWA/A, ROAE, ANNOUNCEMENT AR) on the binary pass / fail stress test outcome of a bank. We find that two out of the six variables display a significant impact at the $5 \%$ significance level: a bank's ASSET QUALITY and ANNOUNCEMENT AR. Hence, a bank's asset quality and its abnormal return at the announcement date significantly affect the likelihood of a stress test failure. Our model produces a pseudo R-squared of 0.814 and hence, does a good job in classifying the stress test outcome of a bank. In line with these results, we find that - when back-testing the model - it correctly classifies 5 out of 6 banks failing the stress test and 157 out of 158 passing the stress test at the time of the announcement. ${ }^{14}$

capitalisation and non-performing exposures at the time of announcement are associated with release outcomes (capital losses). Likewise, Flannery et al. (2015) identify a larger susceptibility to negative abnormal equity returns for riskier banks in CCAR stress tests. Morgan et al. (2014) identify a relationship between announcement returns in predicting result returns.

14 Note that our sample size is reduced in this empirical analysis due to the unavailability of some of the bank characteristics, mostly for smaller US banks. 
In specification (2) we then run an OLS regression (with stress test and year fixed effects) to predict the abnormal equity- and CDS performance of banks at the stress test release. Our results indicate that EXCESS CAP, ASSET QUALITY, LEVERAGE, and RWA/A are significantly related to the abnormal equity return of bank at the time of the stress test release. Hence, banks with a higher capital buffer, higher asset quality, lower leverage, and a less risky business model earn higher abnormal equity returns when the stress test results are made public. Note, that in our regression model, we also control for the abnormal equity return at the announcement day (see the results of Section 4.1); hence, the positive abnormal equity returns at the release are not subsumed by negative abnormal equity returns at the announcement. In terms of economic significance, we find that a one standard deviation increase in EXCESS CAP (decrease in ASSET QUALITY, decrease in LEVERAGE, and decrease in $R W A / A)$ leads to positive abnormal equity returns of $111(37,126,20)$ basis points at the release day. Hence, our results are also economically relevant.

In specification (3) we repeat the investigation of regression model (2), but use abnormal CDS performance as the dependent variable. We observe that abnormal CDS performance at the release day is statistically unrelated to bank characteristics, measured at the announcement day. Note, however, that the weak statistical relationships are enforced by the fact that we only can use data from 73 banks in this analysis due to missing CDS spreads of some financial institutions.

Since stress tests outcomes are (at least) partially predictable, it is likely that banks are optimizing their capital structure accordingly. To investigate this idea, we check 90 bank capital issuances of tested and non-tested banks over the 180-days window before and 180days after the stress test release day and assess the impact the capital increases have on a bank's CET1 ratio. Results are displayed in Figure 2.

\section{[Insert Figure 2 around here]}

Our results indicate that banks which fail their stress test disproportionally increase their capital before the release date. Eight out of ten failing banks, announced their capital raising at least 60 days before the stress test release. The six transactions of failing banks that raised more than USD 500 million were announced 104 days before the stress test release. This clustering is not observable for stress test passing as well as non-tested banks. We argue that capital issuances before the release date have two advantages for stress test failing banks: First, banks can pre-emptively address market concerns regarding insufficient capitalisation that surface with the stress test release. ${ }^{15}$ Second, failing banks anticipate their lack of success and issue new capital before the result release day to mitigate their loss from

\footnotetext{
${ }^{15}$ It is important to highlight that any capital actions conducted in this window will not directly affect stress test outcomes, since the supervisor 'freezes' a bank's balance sheet with the announcement of the stress test.
} 
declining equity prices and widening credit spreads after the public announcement of their stress test failure.

\section{Conclusion}

In this paper we examine the impact of stress testing results and announcements on bank's equity and CDS performance using a large sample of ten tests from the US CCAR and the European EBA regimes in the time period between 2010 and 2017.

For stress test result release events, we show that passing banks experience significantly positive abnormal equity returns of 59 basis points and significantly tighter CDS spreads of 83 basis points, while, failing banks earn significantly negative abnormal equity returns of 206 basis points and widening CDS spreads of 172 basis points. Taken together, the overall effect of stress test releases is performance positive: Tested banks experience significantly positive abnormal equity returns of 36 basis points and significantly tighter CDS spreads of 72 basis points.

For stress tests announcements, we obtain a different picture: Banks, that are going to be stress tested, experience significantly negative abnormal equity returns of 18 basis points and significantly wider CDS spreads of 78 basis points on the announcement day. A possible interpretation of these two contrary effects is, that the overall positive effect of stress tests on bank`s equity and CDS spreads on the result release day compensates investors for negative effects realized on the stress test announcement day. Also, we document that an empirical investigation has to take into account the performance results of both the release and the announcement effect to be viewed as complete.

Finally, we check whether bank fundamentals are able to forecast the final stress test outcome as well as corresponding abnormal equity and CDS performance. Our results indicate that a bank's asset quality and its return of equity at the time of the announcement are significant predictors of the pass/fail outcome of a bank. Moreover, the abnormal equity returns at the release date are predictable at the announcement date using certain bank characteristics. In particular, banks with a higher capital buffer, higher asset quality, lower leverage, and a less risky business model earn higher abnormal equity returns at the stress test release. We find preliminary evidence that banks optimize their capital structure according to this predictability of stress test outcomes. 


\section{Appendix}

\section{Appendix A.1: Survey of stress test event-study literature}

\begin{tabular}{|c|c|c|}
\hline STUDY & $\begin{array}{l}\text { STRESS } \\
\text { TESTS } \\
\text { COVERED }\end{array}$ & FINDINGS \\
\hline $\begin{array}{l}\text { Alves, Mendes and } \\
\text { Pereira da Silva (2015) }\end{array}$ & $\begin{array}{l}\text { EBA } 2010 \\
\text { EBA } 2011\end{array}$ & $\begin{array}{l}\text { Both stress tests affected bank equity performance. } 2010 \text { exercise } \\
\text { promoted a low volatility environment, while } 2011 \text { stress tests } \\
\text { led to increases in volatility post stress test. Comfortably passing } \\
\text { banks experience significantly more positive returns. CDS } \\
\text { markets anticipated some of the results. Reactions are stronger } \\
\text { for riskier institutions. }\end{array}$ \\
\hline Petrella and Resti (2013) & EBA 2011 & $\begin{array}{l}\text { Stress tests have only minor impact on bank equity } \\
\text { performance. Markets were not able to anticipate the results of } \\
\text { stress tests. Stress tests reduce bank opaqueness }\end{array}$ \\
\hline $\begin{array}{l}\text { Georgescu, Gross, Kapp } \\
\text { and Kok (2017) }\end{array}$ & $\begin{array}{l}\text { EBA } 2014 \\
\text { EBA } 2016\end{array}$ & $\begin{array}{l}\text { Both stress tests affected bank equity and CDS performance. } \\
\text { Reactions were stronger for weaker banks. Additional evidence } \\
\text { that stress tests affected sovereign CDS spreads. Significant } \\
\text { market impact of result release as well as announcement. }\end{array}$ \\
\hline $\begin{array}{l}\text { Morgan, Peristiani and } \\
\text { Savino (2014) }\end{array}$ & SCAP 2009 & $\begin{array}{l}\text { Stress tests affected bank's equity and CDS performance during } \\
\text { the SCAP release. Markets anticipated banks with capital gaps, } \\
\text { but the size of the capital gap represented novel information. }\end{array}$ \\
\hline $\begin{array}{l}\text { Flannery, Hirtle and } \\
\text { Kovner (2015) }\end{array}$ & $\begin{array}{l}\text { SCAP } 2009 \\
\text { CCAR } \\
2011-5\end{array}$ & $\begin{array}{l}\text { Stress tests affected banks and banking industry at large. Stress } \\
\text { tests led to higher abnormal trading volume and volatility. } \\
\text { Highly levered banks are affected more. CDS spreads for poorly } \\
\text { capitalized banks decline following the release }\end{array}$ \\
\hline $\begin{array}{l}\text { Neretina, Sahin, and De } \\
\text { Haan (2014) }\end{array}$ & $\begin{array}{l}\text { SCAP } 2009 \\
\text { CCAR } \\
2012-3\end{array}$ & $\begin{array}{l}\text { Stress tests have only minor effects on bank equity. CDS spreads } \\
\text { decline after stress tests. Stress test releases lessen systemic risk. } \\
\text { Considers announcement, methodology, and release events. }\end{array}$ \\
\hline Ellahie (2012) & $\begin{array}{l}\text { EBA } 2010 \\
\text { EBA } 2011\end{array}$ & $\begin{array}{l}\text { Stress tests affected bank equity performance. Stress tests } \\
\text { announcements did not affect performance. EBA sovereign } \\
\text { exposure releases predict equity and CDS performance. }\end{array}$ \\
\hline Candelon and Sy, 2015 & $\begin{array}{l}\text { SCAP } 2009 \\
\text { EBA } 2011\end{array}$ & $\begin{array}{l}\text { Stress tests affected bank equity performance. SCAP } 2009 \\
\text { (strongly positive) and EBA } 2011 \text { (strongly negative) stand out. } \\
\text { Results are predominantly driven by qualitative factors of stress } \\
\text { test design, while capitalization levels are of limited importance. }\end{array}$ \\
\hline
\end{tabular}




\section{Appendix A.2: US and European stress tests}

The three key stress tests conducted by US and European supervisors are briefly outlined below. This study focuses on the latter two.

\section{Dodd-Frank Act Stress Tests (DFAST)}

The DFAST stress testing regime covers US banks with balance sheet sizes ranging from $\$ 10 \mathrm{bn}$ to $\$ 50 \mathrm{bn}$. In general, DFAST presents a less stringent version of the US CCAR. Overall, sophistication of estimation approaches remains limited. For example, capital plan assumptions are based on average, and from 2016 onwards, last years dividends. Stock issuances and repurchases are ignored (Petrella and Resti, 2016). While this approach renders the DFAST highly comparable, it lacks firm-specific considerations. These institutional limitations, as well as, the fact that the focus is on smaller banks, explain why DFAST results are typically overshadowed by CCAR result releases that follow a week later.

\section{Comprehensive Capital Analysis and Review (CCAR):}

The CCAR assesses both a quantitative, as well as, a qualitative dimension of US banks with balance sheets in excess of $\$ 50 \mathrm{bn}$. The quantitative CCAR provides information on banks forecasted capital positions under three Fed-defined economic scenarios. In addition to predefined scenarios, banks include internally developed scenarios that provide a representation of the risks for specific institutions. In contrast to the quantitative part, the qualitative CCAR serves to verify and assess bank internal capital planning processes. This includes an assessment of bank stress testing practices, methodology and governance controls.

\section{European Stress Tests:}

Europe saw an increasing centralisation of stress testing responsibility. The 2010 and 2011 stress tests in the European Union were conducted by the Committee of European Banking Supervisors (CEBS). From 2014 onwards these responsibilities were transferred to the European Banking Authority (EBA), which now runs European stress testing in close coordination with the European Central Bank (ECB). In contrast to CCAR, EBA tests have focused on quantitative outcomes. Recent shifts in the stress testing methodology of EBA tests have and will further align EBA and CCAR, as the European supervisor attributes more weight to qualitative and bank-specific assessments. 


\section{Appendix A.3: List of Bank included in CCAR and EBA stress tests}

This table provides an overview of the banks included in the CCAR stress tests. EQ $\checkmark$ indicates banks with equity event study returns. CDS $\checkmark$ indicates banks with CDS event study returns. Incl. $\checkmark$ indicates banks that were stress tested, all non-tested banks are part of the peer group in that specific year. Pass $\checkmark$ indicates banks that passed the assessment. All data is taken from the official stress test reports available on the Fed website.

Panel A: Banks in CCAR stress tests

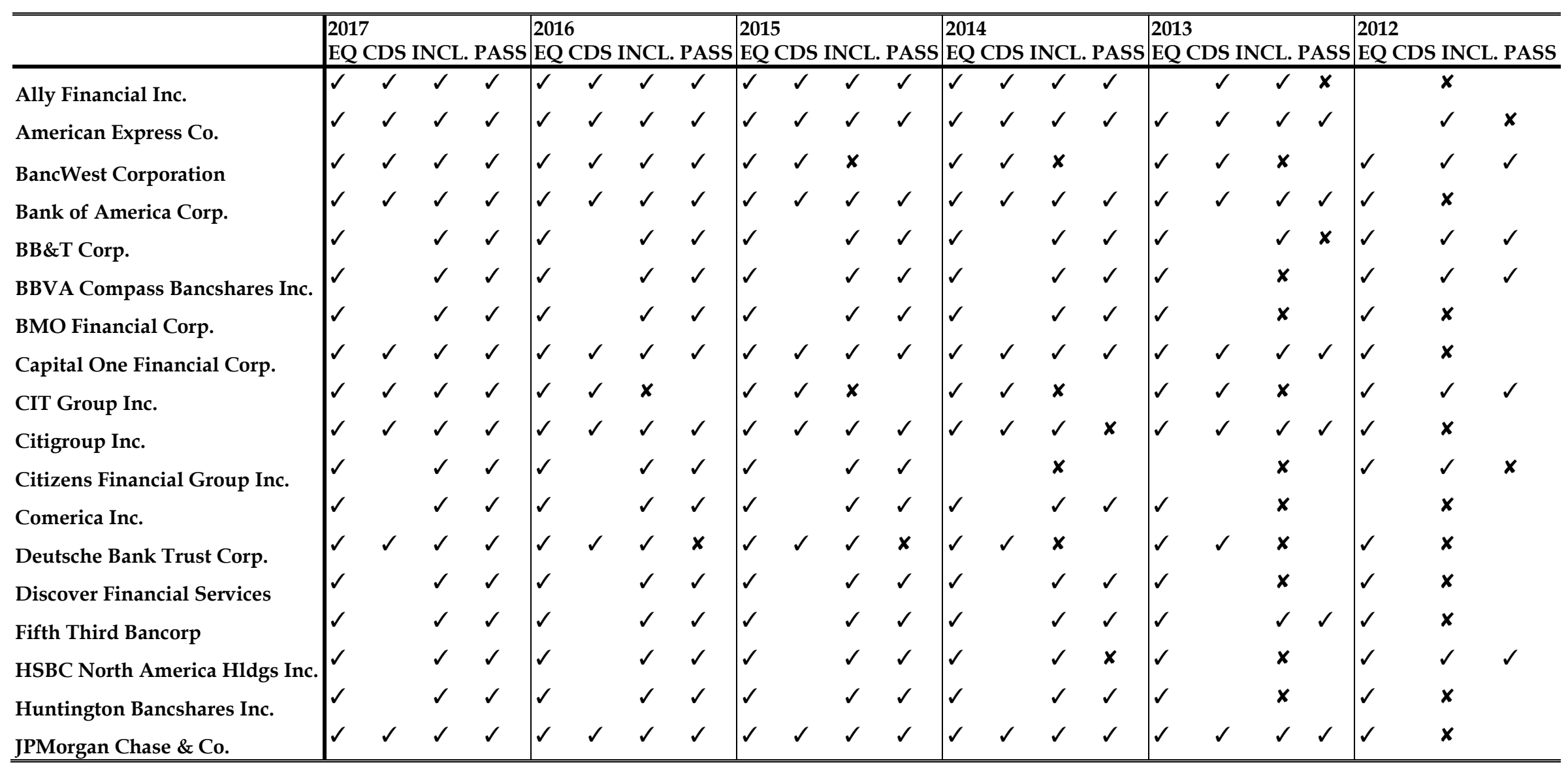




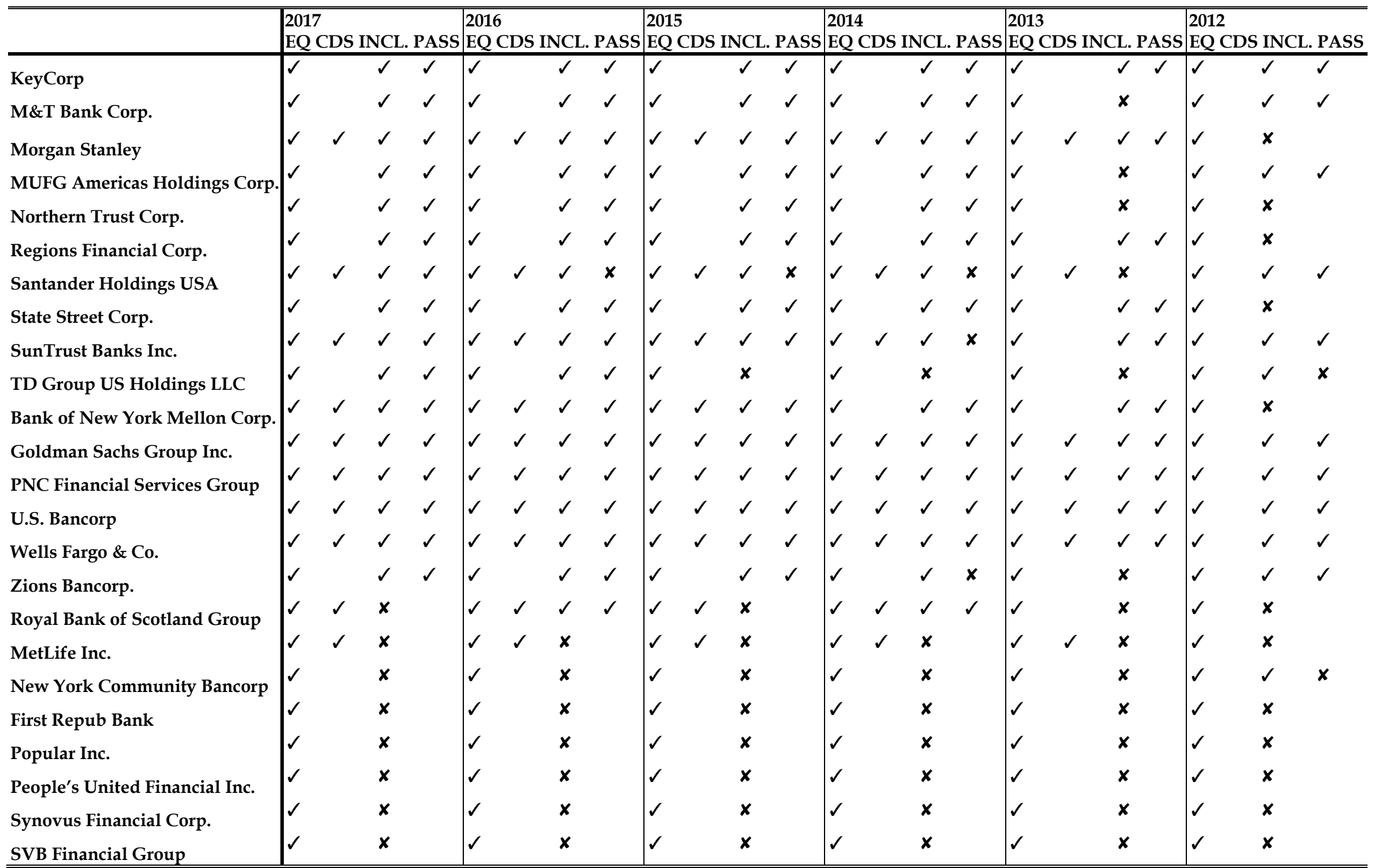




\begin{tabular}{|c|c|c|c|c|c|c|c|c|c|c|c|c|}
\hline & 2017 & & 2016 & & 2015 & & 2014 & & 2013 & & 2012 & \\
\hline & EQ CDS & NCL. PASS & EQ CDS & INCL. PASS & EQ CDS & 5 INCL. PASS & EQ CDS & S INCL. PASS & EQ CDS & S INCL. PASS & EQ CDS & S INCL. PASS \\
\hline BOK Financial Corp. & $\checkmark$ & $x$ & $\checkmark$ & $x$ & $\checkmark$ & $x$ & $\checkmark$ & $x$ & $\checkmark$ & $x$ & $\checkmark$ & $x$ \\
\hline East West Bancorp Inc. & $\checkmark$ & $x$ & $\checkmark$ & $x$ & $\checkmark$ & $x$ & $\checkmark$ & $x$ & $\checkmark$ & $x$ & $\checkmark$ & $x$ \\
\hline First Horizon National Corp. & $\checkmark$ & $x$ & $\checkmark$ & $x$ & $\checkmark$ & $x$ & 4 & $x$ & $\checkmark$ & $x$ & $\checkmark$ & $x$ \\
\hline Associated Banc-Corp & $\checkmark$ & $x$ & $\checkmark$ & $x$ & $\checkmark$ & $x$ & 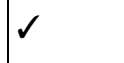 & $x$ & 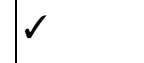 & $x$ & $\checkmark$ & $x$ \\
\hline First Citizens BancShares Inc. & $\checkmark$ & $x$ & $\checkmark$ & $x$ & $\checkmark$ & $x$ & $\checkmark$ & $x$ & $\checkmark$ & $x$ & $\checkmark$ & $x$ \\
\hline Cullen/Frost Bankers Inc. & $\checkmark$ & $x$ & $\checkmark$ & $x$ & $\checkmark$ & $x$ & $\checkmark$ & $x$ & $\checkmark$ & $x$ & $\checkmark$ & $x$ \\
\hline Commerce Bancshares Inc. & $\checkmark$ & $x$ & $\checkmark$ & $x$ & $\checkmark$ & $x$ & 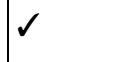 & $x$ & $\checkmark$ & $x$ & $\checkmark$ & $x$ \\
\hline Signature Bank & $\checkmark$ & $x$ & $\checkmark$ & $x$ & $\sqrt{2}$ & $x$ & $\checkmark$ & $x$ & $\checkmark$ & $x$ & $\checkmark$ & $x$ \\
\hline Webster Financial Corp. & $\checkmark$ & $x$ & $\checkmark$ & $x$ & $\checkmark$ & $x$ & 4 & $x$ & $\checkmark$ & $x$ & $\checkmark$ & $x$ \\
\hline TCF Financial Corp. & $\checkmark$ & $x$ & $\checkmark$ & $x$ & $\checkmark$ & $x$ & $\checkmark$ & $x$ & $\checkmark$ & $x$ & $\checkmark$ & $x$ \\
\hline Wintrust Financial Corp. & $\checkmark$ & $x$ & $\checkmark$ & $x$ & $\checkmark$ & $x$ & $\checkmark$ & $x$ & $\checkmark$ & $x$ & $\checkmark$ & $x$ \\
\hline Hancock Holding Co. & $\checkmark$ & $x$ & $\checkmark$ & $x$ & $\checkmark$ & $x$ & $\checkmark$ & $x$ & $\checkmark$ & $x$ & $\checkmark$ & $x$ \\
\hline First Hawaiian Inc. & $\checkmark$ & $x$ & & $x$ & & $x$ & & $x$ & & & $\checkmark$ & $x$ \\
\hline
\end{tabular}


This table provides an overview of the banks included in the EBA stress tests. EQ $\checkmark$ indicates banks with equity event study returns. CDS $\checkmark$ indicates banks with CDS event study returns. Inc $\checkmark$ indicates banks that were stress tested, all non-tested banks are part of the peer group in that specific year. Pass $\checkmark$ indicates banks that passed the assessment. All data is taken from the official stress test reports available on the CEBS and EBA website.

Panel B: Banks in EBA stress tests

\begin{tabular}{|c|c|c|c|c|c|c|c|c|c|c|c|c|c|c|c|c|}
\hline & 2016 & & & & 2014 & & & & 2011 & & & & 2010 & & & \\
\hline & EQ & CDS & INCL. & PASS & EQ & CDS & INCL. & PASS & EQ & CDS & INCL. & PASS & EQ & CDS & INCL. & PASS \\
\hline Aareal Bank & $\checkmark$ & $x$ & $x$ & & $\checkmark$ & $x$ & $\checkmark$ & $\checkmark$ & $\checkmark$ & $x$ & $x$ & & $\checkmark$ & $x$ & $x$ & \\
\hline ABN AMRO Group & $\checkmark$ & $\checkmark$ & $\checkmark$ & $\checkmark$ & $x$ & $\checkmark$ & $\checkmark$ & $\checkmark$ & $x$ & $x$ & $\checkmark$ & $\checkmark$ & $x$ & $x$ & $\checkmark$ & $\checkmark$ \\
\hline Allied Irish Banks & $\checkmark$ & $\checkmark$ & $\checkmark$ & $\checkmark$ & $\checkmark$ & $\checkmark$ & $\checkmark$ & $\checkmark$ & $\checkmark$ & $x$ & $\checkmark$ & $\checkmark$ & $\checkmark$ & $x$ & $\checkmark$ & $\checkmark$ \\
\hline Alpha Bank & $\checkmark$ & $\checkmark$ & $x$ & & $\checkmark$ & $\checkmark$ & $\checkmark$ & $\checkmark$ & $\checkmark$ & $x$ & $\checkmark$ & $\checkmark$ & $\checkmark$ & $x$ & $\checkmark$ & $\checkmark$ \\
\hline Banca Carige & $\checkmark$ & $x$ & $x$ & & $\checkmark$ & $x$ & $\checkmark$ & $x$ & $\checkmark$ & $x$ & $x$ & & $\checkmark$ & $x$ & $x$ & \\
\hline Banca Monte dei Paschi & $\checkmark$ & $\checkmark$ & $\checkmark$ & $\checkmark$ & $\checkmark$ & $\checkmark$ & $\checkmark$ & $x$ & $\checkmark$ & $x$ & $\checkmark$ & $\checkmark$ & $\checkmark$ & $x$ & $\checkmark$ & $\checkmark$ \\
\hline Credito Valtellinese & $\checkmark$ & $x$ & $x$ & & $\checkmark$ & $x$ & $\checkmark$ & $x$ & $\checkmark$ & $x$ & $x$ & & $\checkmark$ & $x$ & $x$ & \\
\hline BPER Banca SpA & $\checkmark$ & $x$ & $x$ & & $\checkmark$ & $x$ & $\checkmark$ & $x$ & $\checkmark$ & $x$ & $x$ & & $\checkmark$ & $x$ & $x$ & \\
\hline Banca Popolare di Sondrio & $\checkmark$ & $x$ & $x$ & & $\checkmark$ & $x$ & $\checkmark$ & $x$ & $\checkmark$ & $x$ & $x$ & & $\checkmark$ & $x$ & $x$ & \\
\hline BBVA & $\checkmark$ & $\checkmark$ & $\checkmark$ & $\checkmark$ & $\checkmark$ & $\checkmark$ & $\checkmark$ & $\checkmark$ & $\checkmark$ & $x$ & $\checkmark$ & $\checkmark$ & $\checkmark$ & $x$ & $\checkmark$ & $\checkmark$ \\
\hline Banco BPI & $\checkmark$ & $\checkmark$ & $x$ & & $\checkmark$ & $\checkmark$ & $\checkmark$ & $\checkmark$ & $\checkmark$ & $x$ & $\checkmark$ & $\checkmark$ & $\checkmark$ & $x$ & $\checkmark$ & $\checkmark$ \\
\hline Millennium BCP & $\checkmark$ & $\checkmark$ & $x$ & & $\checkmark$ & $\checkmark$ & $\checkmark$ & $x$ & $\checkmark$ & $x$ & $\checkmark$ & $\checkmark$ & $\checkmark$ & $x$ & $\checkmark$ & $\checkmark$ \\
\hline Banco de Sabadell & $\checkmark$ & $\checkmark$ & $\checkmark$ & $\checkmark$ & $\checkmark$ & $\checkmark$ & $\checkmark$ & $\checkmark$ & $\checkmark$ & $x$ & $\checkmark$ & $\checkmark$ & $\checkmark$ & $x$ & $\checkmark$ & $\checkmark$ \\
\hline Pastor & $x$ & $x$ & $x$ & & $x$ & $x$ & $x$ & & $\checkmark$ & $x$ & $\checkmark$ & $x$ & $\checkmark$ & $x$ & $\checkmark$ & $\checkmark$ \\
\hline Banco Popular Español & $\checkmark$ & $\checkmark$ & $\checkmark$ & $\checkmark$ & $\checkmark$ & $\checkmark$ & $\checkmark$ & $\checkmark$ & $\checkmark$ & $x$ & $\checkmark$ & $\checkmark$ & $\checkmark$ & $x$ & $\checkmark$ & $\checkmark$ \\
\hline Banco Santander & $\checkmark$ & $\checkmark$ & $\checkmark$ & $\checkmark$ & $\checkmark$ & $\checkmark$ & $\checkmark$ & $\checkmark$ & $\checkmark$ & $x$ & $\checkmark$ & $\checkmark$ & $\sqrt{ }$ & $x$ & $\checkmark$ & $\checkmark$ \\
\hline Bank BPH SA & $\checkmark$ & $x$ & $x$ & & $\checkmark$ & $x$ & $\checkmark$ & $\checkmark$ & $\checkmark$ & $x$ & $x$ & & $\checkmark$ & $x$ & $x$ & \\
\hline Bank Handlowy w Warszawie & $\checkmark$ & $x$ & $x$ & & $\checkmark$ & $x$ & $\checkmark$ & $\checkmark$ & $\checkmark$ & $x$ & $x$ & & $\checkmark$ & $x$ & $x$ & \\
\hline Bank Ochrony Srodowiska & $\checkmark$ & $x$ & $x$ & & $\checkmark$ & $x$ & $\checkmark$ & $\checkmark$ & $\checkmark$ & $x$ & $x$ & & $\checkmark$ & $x$ & $x$ & \\
\hline Bank of Cyprus & $x$ & $x$ & $x$ & & $x$ & $x$ & $\checkmark$ & $x$ & $x$ & $x$ & $\checkmark$ & $\checkmark$ & $x$ & $x$ & $\checkmark$ & $\checkmark$ \\
\hline
\end{tabular}




\begin{tabular}{|c|c|c|c|c|c|c|c|c|c|c|c|c|c|c|c|c|}
\hline & 2016 & & & & 2014 & & & & 2011 & & & & 2010 & & & \\
\hline & EQ & CDS & INCL. & PASS & EQ & CDS & INCL. & PASS & EQ & CDS & INCL. & PASS & EQ & CDS & INCL. & PASS \\
\hline Bank of Valletta & $\checkmark$ & $x$ & $x$ & & $\checkmark$ & $x$ & $\checkmark$ & $\checkmark$ & $\checkmark$ & $x$ & $\checkmark$ & $\checkmark$ & $\checkmark$ & $x$ & $\checkmark$ & $\checkmark$ \\
\hline BFA Tenedora Acciones & $\checkmark$ & $\checkmark$ & $\checkmark$ & $\checkmark$ & $\checkmark$ & $\checkmark$ & $\checkmark$ & $\checkmark$ & $x$ & $x$ & $\checkmark$ & $\checkmark$ & $x$ & $x$ & $x$ & \\
\hline Bankinter & $\checkmark$ & $\checkmark$ & $x$ & & $\checkmark$ & $\checkmark$ & $\checkmark$ & $\checkmark$ & $\checkmark$ & $x$ & $\checkmark$ & $\checkmark$ & $\checkmark$ & $x$ & $\checkmark$ & $\checkmark$ \\
\hline Barclays & $\checkmark$ & $\checkmark$ & $x$ & & $\checkmark$ & $x$ & $\checkmark$ & $\checkmark$ & $\checkmark$ & $x$ & $\checkmark$ & $\checkmark$ & $\checkmark$ & $x$ & $\checkmark$ & $\checkmark$ \\
\hline BNP Paribas & $\checkmark$ & $\checkmark$ & $\checkmark$ & $\checkmark$ & $\checkmark$ & $\checkmark$ & $\checkmark$ & $\checkmark$ & $\checkmark$ & $x$ & $\checkmark$ & $\checkmark$ & $\checkmark$ & $x$ & $\checkmark$ & $\checkmark$ \\
\hline Caja Mediterráneo & $x$ & $\checkmark$ & $x$ & & $x$ & $\checkmark$ & $x$ & & $\checkmark$ & $x$ & $\checkmark$ & $x$ & $\checkmark$ & $x$ & $x$ & \\
\hline Commerzbank & $\checkmark$ & $\checkmark$ & $\checkmark$ & $\checkmark$ & $\checkmark$ & $\checkmark$ & $\checkmark$ & $\checkmark$ & $\checkmark$ & $x$ & $\checkmark$ & $\checkmark$ & $\checkmark$ & $x$ & $\checkmark$ & $\checkmark$ \\
\hline Credito Emiliano & $\checkmark$ & $x$ & $x$ & & $\checkmark$ & $x$ & $\checkmark$ & $x$ & $\checkmark$ & $x$ & $x$ & & $\checkmark$ & $x$ & $x$ & \\
\hline Danske Bank & $\checkmark$ & $\checkmark$ & $\checkmark$ & $\checkmark$ & $\checkmark$ & $\checkmark$ & $\checkmark$ & $\checkmark$ & $\checkmark$ & $x$ & $\checkmark$ & $\checkmark$ & $\checkmark$ & $x$ & $\checkmark$ & $\checkmark$ \\
\hline Deutsche Bank & $\checkmark$ & $\checkmark$ & $\checkmark$ & $\checkmark$ & $\checkmark$ & $\checkmark$ & $\checkmark$ & $\checkmark$ & $\checkmark$ & $x$ & $\checkmark$ & $\checkmark$ & $\checkmark$ & $x$ & $\checkmark$ & $\checkmark$ \\
\hline Deutsche Postbank & $x$ & $x$ & $x$ & & $\checkmark$ & $x$ & $x$ & & $x$ & $x$ & $x$ & & $x$ & $x$ & $\checkmark$ & $\checkmark$ \\
\hline Dexia & $\checkmark$ & $x$ & $x$ & & $\checkmark$ & $x$ & $\checkmark$ & $x$ & $\checkmark$ & $x$ & $\checkmark$ & $\checkmark$ & $\checkmark$ & $x$ & $\checkmark$ & $\checkmark$ \\
\hline Erste Group Bank & $\checkmark$ & $\checkmark$ & $\checkmark$ & $\checkmark$ & $\checkmark$ & $\checkmark$ & $\checkmark$ & $\checkmark$ & $\checkmark$ & $x$ & $\checkmark$ & $\checkmark$ & $\checkmark$ & $x$ & $\checkmark$ & $\checkmark$ \\
\hline Eurobank Ergasias & $\checkmark$ & $\checkmark$ & $x$ & & $\checkmark$ & $\checkmark$ & $\checkmark$ & $x$ & $\checkmark$ & $x$ & $\checkmark$ & $x$ & $\checkmark$ & $x$ & $\checkmark$ & $\checkmark$ \\
\hline FHB Jelzálogbank Nyrt. & $\checkmark$ & $x$ & $x$ & & $\checkmark$ & $x$ & $x$ & & $\checkmark$ & $x$ & $x$ & & $\checkmark$ & $x$ & $\checkmark$ & $\checkmark$ \\
\hline Getin Noble Bank & $\checkmark$ & $x$ & $x$ & & $\checkmark$ & $x$ & $\checkmark$ & $\checkmark$ & $x$ & $x$ & $x$ & & $x$ & $x$ & $x$ & \\
\hline Crédit Agricole Group & $\checkmark$ & $\checkmark$ & $\checkmark$ & $\checkmark$ & $\checkmark$ & $\checkmark$ & $\checkmark$ & $\checkmark$ & $\checkmark$ & $x$ & $\checkmark$ & $\checkmark$ & $\checkmark$ & $x$ & $\checkmark$ & $\checkmark$ \\
\hline Hellenic Bank & $\checkmark$ & $x$ & $x$ & & $\checkmark$ & $x$ & $\checkmark$ & $x$ & $\checkmark$ & $x$ & $x$ & & $\checkmark$ & $x$ & $x$ & \\
\hline IKB Deutsche Industriebank & $\checkmark$ & $\checkmark$ & $x$ & & $\checkmark$ & $\checkmark$ & $\checkmark$ & $\checkmark$ & $\checkmark$ & $x$ & $x$ & & $\checkmark$ & $x$ & $x$ & \\
\hline ING Bank & $\checkmark$ & $\checkmark$ & $x$ & & $\checkmark$ & $\checkmark$ & $\checkmark$ & $\checkmark$ & $\checkmark$ & $x$ & $\checkmark$ & $\checkmark$ & $\checkmark$ & $x$ & $\checkmark$ & $\checkmark$ \\
\hline Argenta Bank & $\checkmark$ & $x$ & $x$ & & $\checkmark$ & $x$ & $\checkmark$ & $\checkmark$ & $x$ & $x$ & $x$ & & $x$ & $x$ & $x$ & \\
\hline Jyske Bank & $\checkmark$ & $x$ & $\checkmark$ & $\checkmark$ & $\checkmark$ & $x$ & $\checkmark$ & $\checkmark$ & $\checkmark$ & $x$ & $\checkmark$ & $\checkmark$ & $\checkmark$ & $x$ & $\checkmark$ & $\checkmark$ \\
\hline KBC Group & $\checkmark$ & $\checkmark$ & $\checkmark$ & $\checkmark$ & $\checkmark$ & $x$ & $\checkmark$ & $\checkmark$ & $\checkmark$ & $x$ & $\checkmark$ & $\checkmark$ & $\checkmark$ & $x$ & $\checkmark$ & $\checkmark$ \\
\hline Landesbank Berlin Holding AG & $x$ & $x$ & $x$ & & $x$ & $x$ & $\checkmark$ & $\checkmark$ & $\checkmark$ & $x$ & $\checkmark$ & $\checkmark$ & $\checkmark$ & $x$ & $\checkmark$ & $\checkmark$ \\
\hline Liberbank SA & $\checkmark$ & $x$ & $x$ & & $\checkmark$ & $x$ & $\checkmark$ & $x$ & $x$ & $x$ & $x$ & & $x$ & $x$ & $x$ & \\
\hline
\end{tabular}




\begin{tabular}{|c|c|c|c|c|c|c|c|c|c|c|c|c|c|c|c|c|}
\hline & 2016 & & & & 2014 & & & & 2011 & & & & 2010 & & & \\
\hline & EQ & CDS & INCL. & PASS & EQ & CDS & INCL. & PASS & EQ & CDS & INCL. & PASS & EQ & CDS & INCL. & PASS \\
\hline Lloyds Banking Group & $\checkmark$ & $\checkmark$ & $\checkmark$ & $\checkmark$ & $\checkmark$ & $\checkmark$ & $\checkmark$ & $\checkmark$ & $\checkmark$ & $x$ & $\checkmark$ & $\checkmark$ & $\checkmark$ & $x$ & $\checkmark$ & $\checkmark$ \\
\hline Mediobanca & $\checkmark$ & $\checkmark$ & $x$ & & $\checkmark$ & $\checkmark$ & $\checkmark$ & $\checkmark$ & $\checkmark$ & $x$ & $x$ & & $\checkmark$ & $x$ & $x$ & \\
\hline National Bank of Greece & $\checkmark$ & $\checkmark$ & $x$ & & $\checkmark$ & $\checkmark$ & $\checkmark$ & $x$ & $\checkmark$ & $x$ & $\checkmark$ & $\checkmark$ & $\checkmark$ & $x$ & $\checkmark$ & $\checkmark$ \\
\hline Nordea Bank & $\checkmark$ & $\checkmark$ & $\checkmark$ & $\checkmark$ & $\checkmark$ & $\checkmark$ & $\checkmark$ & $\checkmark$ & $\checkmark$ & $x$ & $\checkmark$ & $\checkmark$ & $\checkmark$ & $x$ & $\checkmark$ & $\checkmark$ \\
\hline OTP Bank & $\checkmark$ & $x$ & $\checkmark$ & $\checkmark$ & $\checkmark$ & $x$ & $\checkmark$ & $\checkmark$ & $\checkmark$ & $x$ & $\checkmark$ & $\checkmark$ & $\checkmark$ & $x$ & $\checkmark$ & $\checkmark$ \\
\hline Piraeus Bank & $\checkmark$ & $\checkmark$ & $x$ & & $\checkmark$ & $\checkmark$ & $\checkmark$ & $x$ & $\checkmark$ & $x$ & $\checkmark$ & $\checkmark$ & $\checkmark$ & $x$ & $\checkmark$ & $\checkmark$ \\
\hline PKO Bank Polski & $\checkmark$ & $x$ & $\checkmark$ & $\checkmark$ & $\checkmark$ & $x$ & $\checkmark$ & $\checkmark$ & $\checkmark$ & $x$ & $\checkmark$ & $\checkmark$ & $\checkmark$ & $x$ & $\checkmark$ & $\checkmark$ \\
\hline Raiffeisen Bank & $\checkmark$ & $\checkmark$ & $x$ & & $\checkmark$ & $\checkmark$ & $x$ & & $\checkmark$ & $x$ & $\checkmark$ & $\checkmark$ & $\checkmark$ & $x$ & $x$ & \\
\hline Skandinaviska Enskilda Banken & $\checkmark$ & $\checkmark$ & $\checkmark$ & $\checkmark$ & $\checkmark$ & $\checkmark$ & $\checkmark$ & $\checkmark$ & $\checkmark$ & $x$ & $\checkmark$ & $\checkmark$ & $\checkmark$ & $x$ & $\checkmark$ & $\checkmark$ \\
\hline Société Générale & $\checkmark$ & $\checkmark$ & $\checkmark$ & $\checkmark$ & $\checkmark$ & $\checkmark$ & $\checkmark$ & $\checkmark$ & $\checkmark$ & $x$ & $\checkmark$ & $\checkmark$ & $\checkmark$ & $x$ & $\checkmark$ & $\checkmark$ \\
\hline Handelsbanken & $\checkmark$ & $\checkmark$ & $\checkmark$ & $\checkmark$ & $\checkmark$ & $\checkmark$ & $\checkmark$ & $\checkmark$ & $\checkmark$ & $x$ & $\checkmark$ & $\checkmark$ & $\checkmark$ & $x$ & $\checkmark$ & $\checkmark$ \\
\hline Swedbank & $\checkmark$ & $\checkmark$ & $\checkmark$ & $\checkmark$ & $\checkmark$ & $\checkmark$ & $\checkmark$ & $\checkmark$ & $\checkmark$ & $x$ & $\checkmark$ & $\checkmark$ & $\checkmark$ & $x$ & $\checkmark$ & $\checkmark$ \\
\hline Sydbank & $\checkmark$ & $x$ & $x$ & & $\checkmark$ & $x$ & $\checkmark$ & $\checkmark$ & $\checkmark$ & $x$ & $\checkmark$ & $\checkmark$ & $\checkmark$ & $x$ & $\checkmark$ & $\checkmark$ \\
\hline Governor and Co. of the bank & $\checkmark$ & $x$ & $\checkmark$ & $\checkmark$ & $\checkmark$ & $x$ & $\checkmark$ & $\checkmark$ & $\checkmark$ & $x$ & $\checkmark$ & $\checkmark$ & $\checkmark$ & $x$ & $\checkmark$ & $\checkmark$ \\
\hline Royal Bank of Scotland Group & $\checkmark$ & $\checkmark$ & $\checkmark$ & $\checkmark$ & $\checkmark$ & $\checkmark$ & $\checkmark$ & $\checkmark$ & $\checkmark$ & $x$ & $\checkmark$ & $\checkmark$ & $\checkmark$ & $x$ & $\checkmark$ & $\checkmark$ \\
\hline TT Hellenic Postbank & $x$ & $x$ & $x$ & & $x$ & $x$ & $x$ & & $\checkmark$ & $x$ & $\checkmark$ & $\checkmark$ & $\checkmark$ & $x$ & $\checkmark$ & $\checkmark$ \\
\hline UniCredit & $\checkmark$ & $\checkmark$ & $\checkmark$ & $\checkmark$ & $\checkmark$ & $\checkmark$ & $\checkmark$ & $\checkmark$ & $\checkmark$ & $x$ & $\checkmark$ & $\checkmark$ & $\checkmark$ & $x$ & $\checkmark$ & $\checkmark$ \\
\hline UBI Banca & $\checkmark$ & $\checkmark$ & $\checkmark$ & $\checkmark$ & $\checkmark$ & $\checkmark$ & $\checkmark$ & $\checkmark$ & $\checkmark$ & $x$ & $\checkmark$ & $\checkmark$ & $\checkmark$ & $x$ & $\checkmark$ & $\checkmark$ \\
\hline UBS Group & $\checkmark$ & $x$ & $x$ & & $\checkmark$ & $x$ & $x$ & & $\checkmark$ & $x$ & $x$ & & $\checkmark$ & $x$ & $x$ & \\
\hline Credit Suisse & $\checkmark$ & $x$ & $x$ & & $\checkmark$ & $x$ & $x$ & & $\checkmark$ & $x$ & $x$ & & $\checkmark$ & $x$ & $x$ & \\
\hline Standard Chartered & $\checkmark$ & $x$ & $x$ & & $\checkmark$ & $x$ & $x$ & & $\checkmark$ & $x$ & $x$ & & $\checkmark$ & $x$ & $x$ & \\
\hline Banco BPM SpA & $\checkmark$ & $x$ & $x$ & & $\checkmark$ & $x$ & $x$ & & $\checkmark$ & $x$ & $x$ & & $\checkmark$ & $x$ & $x$ & \\
\hline Julius Bär Gruppe & $\checkmark$ & $x$ & $x$ & & $\checkmark$ & $x$ & $x$ & & $\checkmark$ & $x$ & $x$ & & $\checkmark$ & $x$ & $x$ & \\
\hline Bank Pekao SA & $\checkmark$ & $x$ & $x$ & & $\checkmark$ & $x$ & $x$ & & $\checkmark$ & $x$ & $x$ & & $\checkmark$ & $x$ & $x$ & \\
\hline Banque Cantonale Vaudoise & $\checkmark$ & $x$ & $x$ & & $\checkmark$ & $x$ & $x$ & & $\checkmark$ & $x$ & $x$ & & $\checkmark$ & $x$ & $x$ & \\
\hline
\end{tabular}




\begin{tabular}{|c|c|c|c|c|c|c|c|c|c|c|c|c|c|c|c|c|}
\hline & 2016 & & & & 2014 & & & & 2011 & & & & 2010 & & & \\
\hline & EQ & CDS & INCL. & PASS & EQ & CDS & INCL. & PASS & EQ & CDS & INCL. & PASS & EQ & CDS & INCL. & PASS \\
\hline Basler Kantonalbank & $\checkmark$ & $x$ & $x$ & & $\checkmark$ & $x$ & $x$ & & $\checkmark$ & $x$ & $x$ & & $\checkmark$ & $x$ & $x$ & \\
\hline Komercní banka & $\checkmark$ & $x$ & $x$ & & $\checkmark$ & $x$ & $x$ & & $\checkmark$ & $x$ & $x$ & & $\checkmark$ & $x$ & $x$ & \\
\hline Virgin Money Holdings (UK) & $\checkmark$ & $x$ & $x$ & & $x$ & $x$ & $x$ & & $x$ & $x$ & $x$ & & $x$ & $x$ & $x$ & \\
\hline Banca Mediolanum & $\checkmark$ & $x$ & $x$ & & $\checkmark$ & $x$ & $x$ & & $\checkmark$ & $x$ & $x$ & & $\checkmark$ & $x$ & $x$ & \\
\hline mBank SA & $\checkmark$ & $x$ & $x$ & & $\checkmark$ & $x$ & $x$ & & $\checkmark$ & $x$ & $x$ & & $\checkmark$ & $x$ & $x$ & \\
\hline St. Galler Kantonalbank & $\checkmark$ & $x$ & $x$ & & $\checkmark$ & $x$ & $x$ & & $\checkmark$ & $x$ & $x$ & & $\checkmark$ & $x$ & $x$ & \\
\hline DVB Bank & $\checkmark$ & $x$ & $x$ & & $\checkmark$ & $x$ & $x$ & & $\checkmark$ & $x$ & $x$ & & $\checkmark$ & $x$ & $x$ & \\
\hline Bank Zachodni WBK & $\checkmark$ & $x$ & $x$ & & $\checkmark$ & $x$ & $x$ & & $\checkmark$ & $x$ & $x$ & & $\checkmark$ & $x$ & $x$ & \\
\hline EFG International & $\checkmark$ & $x$ & $x$ & & $\checkmark$ & $x$ & $x$ & & $\checkmark$ & $x$ & $x$ & & $\checkmark$ & $x$ & $x$ & \\
\hline Valiant Holding & $\checkmark$ & $x$ & $x$ & & $\checkmark$ & $x$ & $x$ & & $\checkmark$ & $x$ & $x$ & & $\checkmark$ & $x$ & $x$ & \\
\hline Caixa Económica Montepio Geral & $\checkmark$ & $x$ & $x$ & & $\checkmark$ & $x$ & $x$ & & $x$ & $x$ & $x$ & & $x$ & $x$ & $x$ & \\
\hline HSBC Trinkaus \& Burkhardt & $\checkmark$ & $x$ & $x$ & & $\checkmark$ & $x$ & $x$ & & $\checkmark$ & $x$ & $x$ & & $\checkmark$ & $x$ & $x$ & \\
\hline SpareBank 1 SR-Bank & $\checkmark$ & $x$ & $x$ & & $\checkmark$ & $x$ & $x$ & & $\checkmark$ & $x$ & $x$ & & $\checkmark$ & $x$ & $x$ & \\
\hline Vontobel Holding AG & $\checkmark$ & $x$ & $x$ & & $\checkmark$ & $x$ & $x$ & & $\checkmark$ & $x$ & $x$ & & $\checkmark$ & $x$ & $x$ & \\
\hline Sparebanken Vest & $\checkmark$ & $x$ & $x$ & & $\checkmark$ & $x$ & $x$ & & $\checkmark$ & $x$ & $x$ & & $\checkmark$ & $x$ & $x$ & \\
\hline Zagrebaka banka d.d. & $\checkmark$ & $x$ & $x$ & & $\checkmark$ & $x$ & $x$ & & $\checkmark$ & $x$ & $x$ & & $\checkmark$ & $x$ & $x$ & \\
\hline Thurgauer Kantonalbank & $\checkmark$ & $x$ & $x$ & & $\checkmark$ & $x$ & $x$ & & $x$ & $x$ & $x$ & & $x$ & $x$ & $x$ & \\
\hline PJSC ROSBANK & $\checkmark$ & $x$ & $x$ & & $\checkmark$ & $x$ & $x$ & & $\checkmark$ & $x$ & $x$ & & $\checkmark$ & $x$ & $x$ & \\
\hline Oldenburgische Landesbank & $\checkmark$ & $x$ & $x$ & & $\checkmark$ & $x$ & $x$ & & $\checkmark$ & $x$ & $x$ & & $\checkmark$ & $x$ & $x$ & \\
\hline Banco Popolare & $x$ & $\checkmark$ & $\checkmark$ & $\checkmark$ & $x$ & $\checkmark$ & $\checkmark$ & $x$ & $x$ & $x$ & $\checkmark$ & $\checkmark$ & $x$ & $x$ & $\checkmark$ & $\checkmark$ \\
\hline Banque PSA Finance SA & $x$ & $\checkmark$ & $x$ & & $x$ & $\checkmark$ & $\checkmark$ & $\checkmark$ & $x$ & $x$ & $x$ & & $x$ & $x$ & $x$ & \\
\hline Barclays Bank Plc & $x$ & $\checkmark$ & $\checkmark$ & $\checkmark$ & $x$ & $\checkmark$ & $x$ & & $x$ & $x$ & $x$ & & $x$ & $x$ & $x$ & \\
\hline BAWAG PSK & $x$ & $\checkmark$ & $x$ & & $x$ & $\checkmark$ & $\checkmark$ & $\checkmark$ & $x$ & $x$ & $x$ & & $x$ & $x$ & $x$ & \\
\hline Bayerische Landesbank & $x$ & $\checkmark$ & $\checkmark$ & $\checkmark$ & $x$ & $\checkmark$ & $\checkmark$ & $\checkmark$ & $x$ & $x$ & $\checkmark$ & $\checkmark$ & $x$ & $x$ & $\checkmark$ & $\checkmark$ \\
\hline Caixa Geral & $x$ & $\checkmark$ & $x$ & & $x$ & $\checkmark$ & $\checkmark$ & $\checkmark$ & $x$ & $x$ & $\checkmark$ & $\checkmark$ & $x$ & $x$ & $\checkmark$ & $\checkmark$ \\
\hline
\end{tabular}




\begin{tabular}{|c|c|c|c|c|c|c|c|c|c|c|c|c|c|c|c|c|}
\hline & 2016 & & & & 2014 & & & & 2011 & & & & 2010 & & & \\
\hline & EQ & CDS & INCL. & PASS & EQ & CDS & INCL. & PASS & EQ & CDS & INCL. & PASS & EQ & CDS & INCL. & PASS \\
\hline Fundación Bancaria Ibercaja & $x$ & $x$ & $x$ & & $x$ & $x$ & $\checkmark$ & $\checkmark$ & $x$ & $x$ & $x$ & & $x$ & $x$ & $x$ & \\
\hline Fundación Bancaria La Caixa & $x$ & $\checkmark$ & $x$ & & $x$ & $\checkmark$ & $x$ & & $x$ & $x$ & $\checkmark$ & $\checkmark$ & $x$ & $x$ & $x$ & \\
\hline Raiffeisen-Boerenleenbank & $x$ & $\checkmark$ & $x$ & & $x$ & $\checkmark$ & $\checkmark$ & $\checkmark$ & $x$ & $x$ & $x$ & & $x$ & $x$ & $x$ & \\
\hline CaixaBank & $x$ & $\checkmark$ & $\checkmark$ & $\checkmark$ & $x$ & $\checkmark$ & $\checkmark$ & $\checkmark$ & $x$ & $x$ & $x$ & & $x$ & $x$ & $x$ & \\
\hline DNB Bank ASA & $x$ & $\checkmark$ & $\checkmark$ & $\checkmark$ & $x$ & $x$ & $x$ & & $x$ & $x$ & $\checkmark$ & $\checkmark$ & $x$ & $x$ & $x$ & \\
\hline DNB ASA & $x$ & $\checkmark$ & $x$ & & $x$ & $\checkmark$ & $\checkmark$ & $\checkmark$ & $x$ & $x$ & $x$ & & $x$ & $x$ & $x$ & \\
\hline DZ BANK AG & $x$ & $\checkmark$ & $x$ & & $x$ & $\checkmark$ & $\checkmark$ & $\checkmark$ & $x$ & $x$ & $\checkmark$ & $\checkmark$ & $x$ & $x$ & $\checkmark$ & $\checkmark$ \\
\hline Groupe BPCE & $x$ & $\checkmark$ & $\checkmark$ & $\checkmark$ & $x$ & $x$ & $\checkmark$ & $\checkmark$ & $x$ & $x$ & $\checkmark$ & $\checkmark$ & $x$ & $x$ & $\checkmark$ & $\checkmark$ \\
\hline Crédit Mutuel Group & $x$ & $\checkmark$ & $\checkmark$ & $\checkmark$ & $x$ & $\checkmark$ & $\checkmark$ & $\checkmark$ & $x$ & $x$ & $x$ & & $x$ & $x$ & $x$ & \\
\hline HSH Nordbank & $x$ & $\checkmark$ & $x$ & & $x$ & $\checkmark$ & $\checkmark$ & $\checkmark$ & $x$ & $x$ & $\checkmark$ & $\checkmark$ & $x$ & $x$ & $\checkmark$ & $\checkmark$ \\
\hline ING Groep & $x$ & $\checkmark$ & $\checkmark$ & $\checkmark$ & $x$ & $\checkmark$ & $x$ & & $x$ & $x$ & $x$ & & $x$ & $x$ & $x$ & \\
\hline Intesa Sanpaolo & $x$ & $\checkmark$ & $\checkmark$ & $\checkmark$ & $x$ & $\checkmark$ & $\checkmark$ & $\checkmark$ & $x$ & $x$ & $\checkmark$ & $\checkmark$ & $x$ & $x$ & $\checkmark$ & $\checkmark$ \\
\hline Landesbank Baden-Württemberg & $x$ & $\checkmark$ & $\checkmark$ & $\checkmark$ & $x$ & $\checkmark$ & $\checkmark$ & $\checkmark$ & $x$ & $x$ & $\checkmark$ & $\checkmark$ & $x$ & $x$ & $\checkmark$ & $\checkmark$ \\
\hline Landesbank Hessen-Thüringen & $x$ & $\checkmark$ & $\checkmark$ & $\checkmark$ & $x$ & $\checkmark$ & $\checkmark$ & $\checkmark$ & $x$ & $x$ & $\checkmark$ & $x$ & $x$ & $x$ & $\checkmark$ & $\checkmark$ \\
\hline NORD/LB & $x$ & $\checkmark$ & $\checkmark$ & $\checkmark$ & $x$ & $\checkmark$ & $\checkmark$ & $\checkmark$ & $x$ & $x$ & $\checkmark$ & $\checkmark$ & $x$ & $x$ & $\checkmark$ & $\checkmark$ \\
\hline Permanent TSB Group Hldgs Plc & $x$ & $\checkmark$ & $x$ & & $x$ & $\checkmark$ & $\checkmark$ & $x$ & $x$ & $x$ & $x$ & & $x$ & $x$ & $x$ & \\
\hline Raiffeisen Zentralbank & $x$ & $\checkmark$ & $\checkmark$ & $\checkmark$ & $x$ & $\checkmark$ & $\checkmark$ & $\checkmark$ & $x$ & $x$ & $x$ & & $x$ & $x$ & $\checkmark$ & $\checkmark$ \\
\hline RCI Banque SA & $x$ & $\checkmark$ & $x$ & & $x$ & $x$ & $\checkmark$ & $\checkmark$ & $x$ & $x$ & $x$ & & $x$ & $x$ & $x$ & \\
\hline Volksbank NV & $x$ & $x$ & $x$ & & $x$ & $\checkmark$ & $\checkmark$ & $\checkmark$ & $x$ & $x$ & $\checkmark$ & $\checkmark$ & $x$ & $x$ & $\checkmark$ & $\checkmark$ \\
\hline Portigon AG & $x$ & $\checkmark$ & $x$ & & $x$ & $\checkmark$ & $x$ & & $x$ & $x$ & $\checkmark$ & $\checkmark$ & $x$ & $x$ & $\checkmark$ & $\checkmark$ \\
\hline
\end{tabular}




\section{References}

Alves, C., Mendes, V., and Pereira da Silva, P. (2015). Do stress tests matter? A study on the impact of the disclosure of stress test results on European financial stocks and CDS markets. Applied Economics, 47, 1213-1229.

Barucci, E., Baviera, R., and Milani, C. (2018). The comprehensive assessment: What lessons can be learned? European Journal of Finance, Forthcoming.

Candelon, B., and Sy, A. (2015). How did markets react to stress tests? Working Paper, IMF.

Carboni, M., Fiordelisi, F., Ricci, O., and Lopes, F. S. S. (2017). Surprised or not surprised? The investors' reaction to the comprehensive assessment preceding the launch of the banking union. Journal of Banking and Finance, 74, 122-132.

Ellahie, A. (2012). Capital market consequences of EU bank stress tests. Working Paper, London Business School.

Fama, E. F., Fisher, L., Jensen, M. C., and Roll, R. (1969). The adjustment of stock prices to new information. International Economic Review, 10, 1-21.

Flannery, M., Hirtle, B., and Kovner, A. (2015). Evaluating the information in the Federal Reserve stress tests. Working Paper, Federal Reserve Bank of New York.

Georgescu, O.-M., Gross, M., Kapp, D., and Kok, C. (2017). Do stress tests matter? Evidence from the 2014 and 2016 stress tests. Working Paper, ECB.

Glasserman, P., and Tangirala, G. (2015). Are the Federal Reserve's stress test results predictable? Working Paper, Office of Financial Research (OFR).

Goldstein, I., and Leitner, Y. (2015). Stress tests and information disclosures. Working Paper, Federal Reserve Bank of Philadelphia.

Goldstein, I., and Sapra, H. (2014). Should banks' stress test results be disclosed? An Analysis of the Costs and Benefits. Foundations and Trends in Finance, 8, 1-54.

MacKinlay, A. C. (1997). Event studies in economics and finance. Journal of Economic Literature, 35, 13-39.

Morgan, D. P., Peristiani, S., and Savino, V. (2014). The information value of the stress test and bank opacity. Journal of Money, Credit and Banking, 46, 1479-1500.

Neretina, E., Sahin, C., and De Haan, J. (2014). Bank stress test effects on returns and risks. Working Paper, De Nederlandsche Bank.

Petrella, G., and Resti, A. (2013). Supervisors as information producers: Do stress tests reduce bank opaqueness? Journal of Banking and Finance, 37, 5406-5420.

Petrella, G., and Resti, A. (2016). The interplay between banks and markets: Supervisory stress test results and investor reactions. In T. Beck and B. Casu (Eds.), The Palgrave Handbook of European Banking, 401-691.

Sharpe, W. F. (1964). Capital asset prices: A theory of market equilibrium under conditions of risk. Journal of Finance, 19, 425-442. 


\section{Figures}

Figure 1: Timeline of stress tests

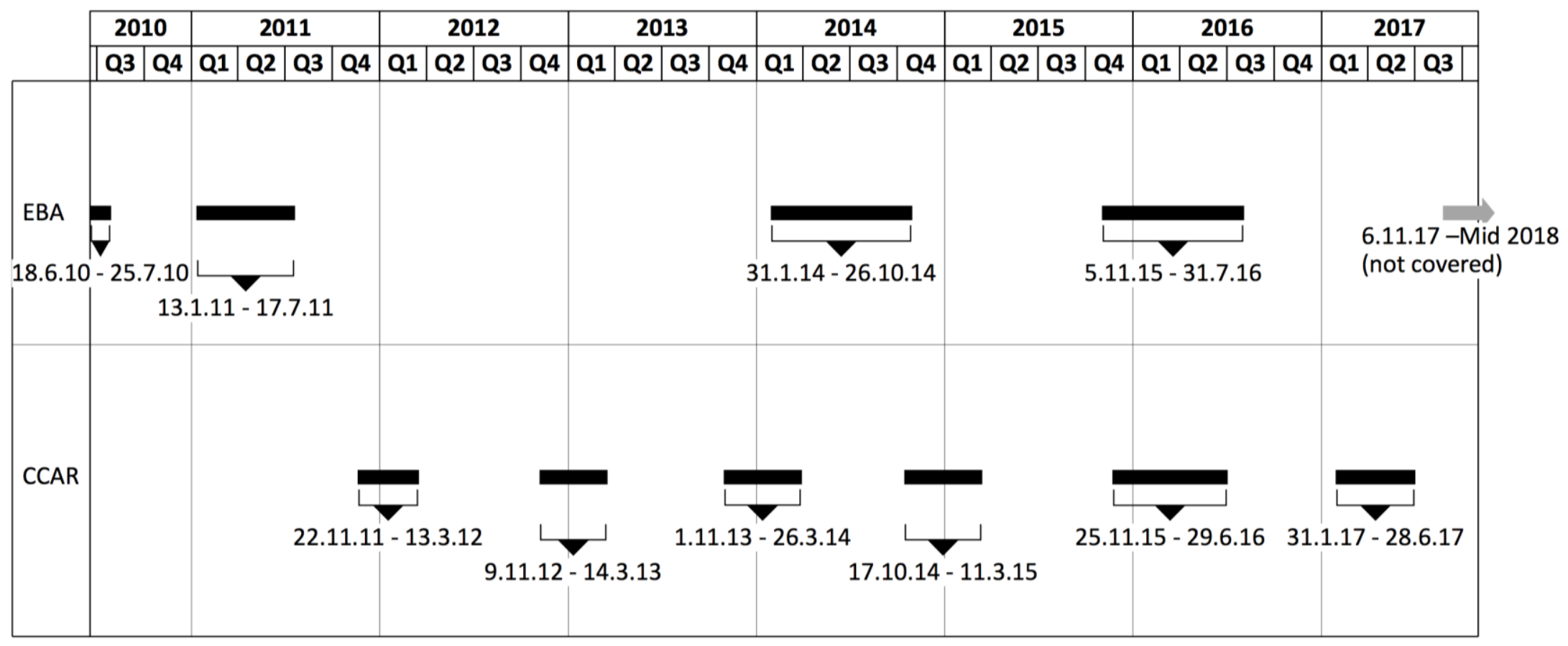

Figure 1 illustrates the timeline of stress tests considered in this study. We cover all ten important recent stress tests conducted in the US and Europe in the time period from 2010 to 2017. The stress test announcement date is defined as the first communication of supervisors to the public in a stress testing cycle. The result release date is defined as the next available trading day after stress test results are published. All data from the US taken from the official stress test reports available on the Fed website. All data from Europe is taken from the official stress test reports available on the CEBS and EBA website. 
Figure 2: Patterns in bank capital issuances

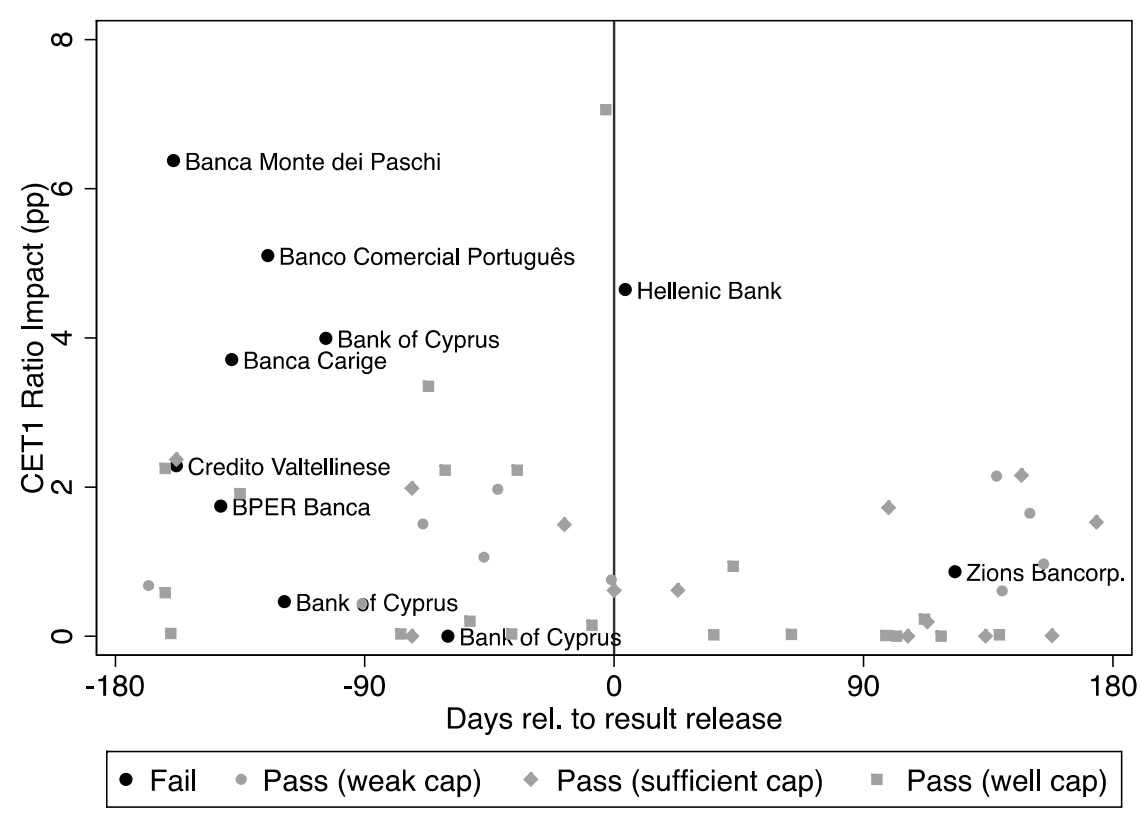

Figure 2 illustrates the timing and magnitude of bank capital market actions for 53 stress tested banks. We use the nominal size of the capital increases to determine the percentage point impact the action has on the CET1 capitalisation of the bank. The capital market action announcement date is plotted in relation to the respective stress test result announcement date. All banks that conducted capital market actions and failed the stress test in the 6-month period are labelled with names. The markers illustrate different capitalisation levels of passing banks. Data is sourced from SNL Financial and Reuters. 
Tables

Table 1: Key features of stress tests studied

\begin{tabular}{|c|c|c|c|c|c|c|c|c|c|c|}
\hline & \multicolumn{4}{|c|}{ EBA } & \multicolumn{6}{|c|}{ CCAR } \\
\hline & 2010 & 2011 & 2014 & 2016 & 2012 & 2013 & 2014 & 2015 & 2016 & 2017 \\
\hline $\begin{array}{l}\text { Announcement } \\
\text { Date }\end{array}$ & $18 / 6 / 2010$ & $13 / 1 / 2011$ & $31 / 1 / 2014$ & $5 / 11 / 2015$ & $22 / 11 / 2011$ & $9 / 11 / 2012$ & $1 / 11 / 2013$ & $17 / 10 / 2014$ & $25 / 11 / 2015$ & $31 / 1 / 2017$ \\
\hline Release Date & $26 / 7 / 2010$ & $18 / 7 / 2011$ & $27 / 10 / 2014$ & $1 / 8 / 2016$ & $14 / 3 / 2012$ & $15 / 3 / 2013$ & $27 / 3 / 2014$ & $12 / 3 / 2015$ & $30 / 6 / 2016$ & $29 / 6 / 2017$ \\
\hline $\begin{array}{l}\text { Competent } \\
\text { authority }\end{array}$ & CEBS & CEBS & EBA & EBA & Fed & Fed & Fed & Fed & Fed & Fed \\
\hline $\begin{array}{l}\text { \# banks tested } \\
\text { (of which in } \\
\text { sample }^{*} \text { ) }\end{array}$ & $\begin{array}{l}91 \\
(59)\end{array}$ & $\begin{array}{l}90 \\
(61)\end{array}$ & $\begin{array}{l}130 \\
(79)\end{array}$ & $\begin{array}{l}51 \\
(42)\end{array}$ & $\begin{array}{l}19 \\
(19)\end{array}$ & $\begin{array}{l}18 \\
(18)\end{array}$ & $\begin{array}{l}30 \\
(30)\end{array}$ & $\begin{array}{l}31 \\
(31)\end{array}$ & $\begin{array}{l}34 \\
(34)\end{array}$ & $\begin{array}{l}34 \\
(34)\end{array}$ \\
\hline $\begin{array}{l}\text { \# banks failed } \\
\text { (of which in } \\
\text { sample) }\end{array}$ & $\begin{array}{c}7 \\
(0)\end{array}$ & $\begin{array}{l}8 \\
(4)\end{array}$ & $\begin{array}{l}25 \\
(16)\end{array}$ & - & $\begin{array}{l}4 \\
(4)\end{array}$ & $\begin{array}{l}2 \\
(2)\end{array}$ & $\begin{array}{l}5 \\
(5)\end{array}$ & $\begin{array}{l}2 \\
(2)\end{array}$ & $\begin{array}{l}2 \\
(2)\end{array}$ & - \\
\hline Hurdle rate ${ }^{* *}$ & $6 \% \mathrm{~T} 1$ & 5\% CET1 & $5 \%$ CET1 & $5.5 \%$ CET1 & $4 \% \mathrm{~T} 1$ & $5 \% \mathrm{~T} 1$ & 4.5\% CET1 & 4.5\% CET1 & 4.5\% CET1 & $4.5 \%$ CET1 \\
\hline $\begin{array}{l}\text { Regulatory } \\
\text { follow-up }\end{array}$ & None & $\begin{array}{l}\text { Up to nat. } \\
\text { supervisors }\end{array}$ & $\begin{array}{l}\text { Compulsory } \\
\text { capital }\end{array}$ & $\begin{array}{l}\text { None; } \\
\text { Results used } \\
\text { in SREP }\end{array}$ & \multicolumn{6}{|c|}{$\begin{array}{l}\text { Failed institutions must not pursue their current capital plan, typically this includes freezing } \\
\text { dividends and share repurchases for a period of at least } 12 \text { months }\end{array}$} \\
\hline Scenarios & \multicolumn{4}{|c|}{ Two scenarios on a three-year horizon. } & \multicolumn{6}{|c|}{$\begin{array}{l}\text { Three scenarios on a nine-quarter horizon. More recently CCAR tests have switched to a five- } \\
\text { scenario approach, of which two are generated by the bank. }\end{array}$} \\
\hline
\end{tabular}

Table 1 reports key features of the stress tests investigated in this study. We cover all ten important recent stress tests conducted in the US and Europe in the time period from 2010 to 2017. For each stress test, we report the announcement date, the release date, the competent authority, the number of banks tested, the number of banks failed, the hurdle rate, the regulatory follow-up, and the stress test scenarios. *denotes the number of banks with equity and/or CDS spreads available. **This study focuses on the hurdle rate regarding the lowest tier of regulatory capital (typically CET1). This represents the key hurdle for banks to pass. All data from the US taken from the official stress test reports available on the Fed website. All data from Europe is taken from the official stress test reports available on the CEBS and EBA website. 
Table 2: Result performance summary - Pass vs. Fail

\begin{tabular}{|c|c|c|c|c|c|c|c|c|}
\hline & \begin{tabular}{|l|} 
Pass \\
$E Q A R$ \\
\end{tabular} & $E Q C A R$ & CDS AR & CDS CAR & $\begin{array}{l}\text { Fail } \\
E Q A R\end{array}$ & $E Q C A R$ & CDS AR & CDS CAR \\
\hline CCAR 2012 & $\begin{array}{l}0.66 \\
(1.04)\end{array}$ & $\begin{array}{l}-0.16 \\
(0.26)\end{array}$ & & & $\begin{array}{l}-2.35 \\
(0.72)\end{array}$ & $\begin{array}{l}-3.9 \\
(1.34)\end{array}$ & & \\
\hline CCAR 2013 & $\begin{array}{l}1.17^{* *} \\
(2.80)\end{array}$ & $\begin{array}{l}0.28 \\
(0.66)\end{array}$ & $\begin{array}{l}0.62 \\
(0.92)\end{array}$ & $\begin{array}{l}-3.15^{* *} \\
(2.86)\end{array}$ & -1.97 & -2.12 & -0.99 & -5.48 \\
\hline CCAR 2014 & $\begin{array}{l}-0.41^{*} \\
(1.79)\end{array}$ & $\begin{array}{l}-0.23 \\
(0.74)\end{array}$ & $\begin{array}{l}1.17^{* *} \\
(2.32)\end{array}$ & $\begin{array}{l}1.95^{*} \\
(2.25)\end{array}$ & $\begin{array}{l}-1.4 \\
(1.37)\end{array}$ & $\begin{array}{l}-0.72 \\
(0.41)\end{array}$ & $\begin{array}{l}3.04 \\
(2.12)\end{array}$ & $\begin{array}{l}2.22 \\
(0.82)\end{array}$ \\
\hline CCAR 2015 & $\begin{array}{l}1.63^{* * *} \\
(6.94)\end{array}$ & $\begin{array}{l}-0.07 \\
(0.25)\end{array}$ & $\begin{array}{l}0.04 \\
(0.07)\end{array}$ & $\begin{array}{l}-1.93^{* *} \\
(2.99)\end{array}$ & $\begin{array}{l}-1.1 \\
(1.67)\end{array}$ & $\begin{array}{l}-0.45 \\
(0.65)\end{array}$ & $\begin{array}{l}1.84 \\
(2.65)\end{array}$ & $\begin{array}{l}-5.36^{*} \\
(7.61)\end{array}$ \\
\hline CCAR 2016 & $\begin{array}{l}0.18 \\
(0.53)\end{array}$ & $\begin{array}{l}1.05^{* *} \\
(2.52)\end{array}$ & $\begin{array}{l}-0.66 \\
(1.19)\end{array}$ & $\begin{array}{l}-8.22^{* * *} \\
(6.16)\end{array}$ & $\begin{array}{l}-4.22^{*} \\
(5.91)\end{array}$ & $\begin{array}{l}-1.33 \\
(0.56)\end{array}$ & $\begin{array}{l}3.47 \\
(5.02)\end{array}$ & $\begin{array}{l}-7.26 \\
(5.25)\end{array}$ \\
\hline CCAR 2017 & $\begin{array}{l}0.74^{* * *} \\
(3.05)\end{array}$ & $\begin{array}{l}0.78^{* * *} \\
(2.89)\end{array}$ & $\begin{array}{l}-1.12^{* *} \\
(2.50)\end{array}$ & $\begin{array}{l}2.50 \\
(0.87)\end{array}$ & & & & \\
\hline CCAR Total & $\begin{array}{l}0.64^{\star * *} \\
(4.52)\end{array}$ & $\begin{array}{l}0.36^{* *} \\
(2.35)\end{array}$ & $\begin{array}{l}-0.14 \\
(0.54)\end{array}$ & $\begin{array}{l}-1.76^{*} \\
(1.83)\end{array}$ & $\begin{array}{l}-2.04^{* *} \\
(2.59)\end{array}$ & $\begin{array}{l}-1.61 \\
(1.66)\end{array}$ & $\begin{array}{l}2.34^{* *} \\
(3.20)\end{array}$ & $\begin{array}{l}-3.01 \\
(1.66)\end{array}$ \\
\hline $\mathrm{N}$ & 151 & 151 & 66 & 66 & & & 8 & 8 \\
\hline EBA 2010 & $\begin{array}{l}1.14^{\star * *} \\
(2.73)\end{array}$ & $\begin{array}{l}2.04^{* * *} \\
(2.80)\end{array}$ & & & & & & \\
\hline EBA 2011 & $\begin{array}{l}0.06 \\
(0.14)\end{array}$ & $\begin{array}{l}0.16 \\
(0.38)\end{array}$ & & & $\begin{array}{l}0.85 \\
(1.22)\end{array}$ & $\begin{array}{l}2.45 \\
(2.90)\end{array}$ & & \\
\hline EBA 2014 & $\begin{array}{l}0.7^{* *} \\
(2.21)\end{array}$ & $\begin{array}{l}0.31 \\
(0.70)\end{array}$ & $\begin{array}{l}-2.14^{* * *} \\
(3.07)\end{array}$ & $\begin{array}{l}-2.02^{* *} \\
(2.07)\end{array}$ & $\begin{array}{l}-2.76 \\
(1.30)\end{array}$ & $\begin{array}{l}-1.54 \\
(0.94)\end{array}$ & $\begin{array}{l}0.89 \\
(0.81)\end{array}$ & $\begin{array}{l}1.04 \\
(0.52)\end{array}$ \\
\hline EBA 2016 & $\begin{array}{l}0.11 \\
(0.18)\end{array}$ & $\begin{array}{l}-1.10 \\
(1.50)\end{array}$ & $\begin{array}{l}-0.48 \\
(1.11)\end{array}$ & $\begin{array}{l}-2.05^{* * *} \\
(4.14)\end{array}$ & & & & \\
\hline $\begin{array}{l}\text { EBA Total } \\
\mathrm{N}\end{array}$ & $\begin{array}{l}0.54^{* *} \\
(2.54) \\
155\end{array}$ & $\begin{array}{l}0.49 \\
(1.59) \\
155\end{array}$ & $\begin{array}{l}-1.38^{* * *} \\
(3.17) \\
83\end{array}$ & $\begin{array}{l}-2.03^{* * *} \\
(3.57) \\
83\end{array}$ & $\begin{array}{l}-2.08 \\
(1.19) \\
16\end{array}$ & $\begin{array}{l}-0.79 \\
(0.57) \\
16\end{array}$ & $\begin{array}{l}0.89 \\
(0.81) \\
6\end{array}$ & $\begin{array}{l}1.04 \\
(0.52) \\
6\end{array}$ \\
\hline Combined & $\begin{array}{l}0.59 * * * \\
(4.60) \\
306\end{array}$ & $\begin{array}{l}0.43^{* *} \\
(2.48) \\
306\end{array}$ & $\begin{array}{l}-0.83^{* * *} \\
(3.05) \\
149\end{array}$ & $\begin{array}{l}-1.91^{* *} \\
(3.61) \\
149\end{array}$ & $\begin{array}{l}-2.06^{*} \\
(2.03) \\
29\end{array}$ & $\begin{array}{l}-1.16 \\
(1.33) \\
29\end{array}$ & $\begin{array}{l}1.72^{* *} \\
(2.79) \\
14\end{array}$ & $\begin{array}{l}-1.27 \\
(0.90) \\
14\end{array}$ \\
\hline
\end{tabular}

Table 2 provides results of the empirical impact of the stress test release outcome banks' equity and CDS performance for passing and failing banks. We estimate average abnormal equity and CDS performance for passing and failing banks according to the description in Section 2.2. AR refers to the abnormal returns computed using a 1-day estimation window. CAR refers to the abnormal returns computed using a 3-day $(-1,+1)$ estimation window. ***, **, and * denotes statistical significance at the $1 \%, 5 \%$, and $10 \%$ level, respectively. All data from the US is taken from the official stress test reports available on the Fed website. All data from Europe is taken from the official stress test reports available on the CEBS and EBA website. We obtain daily perbank equity prices from Reuters Datastream and CDS spreads (5 year-senior) from the S\&P's SNL Financial Database. 
Table 3: Result performance summary - Tested vs. Non-Tested

\begin{tabular}{|c|c|c|c|c|c|c|c|c|}
\hline & \multicolumn{4}{|l|}{ Tested } & \multicolumn{4}{|c|}{ Non-Tested } \\
\hline & EQ AR & EQ CAR & CDS AR & CDS CAR & EQ AR & EQ CAR & CDS AR & CDS CAR \\
\hline CCAR 2012 & $\begin{array}{l}0.17 \\
(0.23)\end{array}$ & $\begin{array}{l}-0.79 \\
(1.06)\end{array}$ & & & \begin{tabular}{|l|}
0.42 \\
$(1.04)$
\end{tabular} & $\begin{array}{l}-0.71 \\
(1.60)\end{array}$ & & \\
\hline CCAR 2013 & $\begin{array}{l}0.99^{* *} \\
(2.27)\end{array}$ & $\begin{array}{l}0.14 \\
(0.33)\end{array}$ & $\begin{array}{l}0.48 \\
(0.76)\end{array}$ & $\begin{array}{l}-3.36^{* * *} \\
(3.30)\end{array}$ & $\begin{array}{l}0.29 \\
1.67)\end{array}$ & $\begin{array}{l}-0.04 \\
(0.17)\end{array}$ & $\begin{array}{r}-1.02^{*} \\
(2.28)\end{array}$ & $\begin{array}{l}0.29 \\
(0.15)\end{array}$ \\
\hline CCAR 2014 & $\begin{array}{l}-0.58^{* *} \\
(2.26)\end{array}$ & $\begin{array}{l}-0.31 \\
(0.84)\end{array}$ & $\begin{array}{l}1.57^{* * *} \\
(3.04)\end{array}$ & $\begin{array}{l}2.01^{* *} \\
(2.41)\end{array}$ & $\begin{array}{l}-1.51^{* * *} \\
(9.30)\end{array}$ & $\begin{array}{l}-1.88^{\text {tox }} \\
(6.05)\end{array}$ & $\begin{array}{l}0.62 \\
(1.22)\end{array}$ & $\begin{array}{l}-0.27 \\
(0.34)\end{array}$ \\
\hline CCAR 2015 & $\begin{array}{l}1.46^{* * *} \\
(5.74)\end{array}$ & $\begin{array}{c}-0.09 \\
(0.37)\end{array}$ & $\begin{array}{l}0.28 \\
(0.51)\end{array}$ & $\begin{array}{l}-2.39^{* * *} \\
(3.72)\end{array}$ & $\begin{array}{l}0.92^{* * *} \\
(4.71)\end{array}$ & $\begin{array}{l}-0.85^{* *} \\
(2.60)\end{array}$ & $\begin{array}{l}0.83 \\
(0.93)\end{array}$ & $\begin{array}{l}-1.99 \\
(1.44)\end{array}$ \\
\hline CCAR 2016 & $\begin{array}{l}-0.08 \\
(0.21)\end{array}$ & $\begin{array}{l}0.91^{* *} \\
(2.19)\end{array}$ & $\begin{array}{l}-0.17 \\
(0.28)\end{array}$ & $\begin{array}{l}-8.11^{* * *} \\
(6.86)\end{array}$ & $\begin{array}{l}0.67^{* * *} \\
(2.92)\end{array}$ & $\begin{array}{l}1.07^{* * *} \\
(2.93)\end{array}$ & $\begin{array}{l}1.10 \\
(0.55)\end{array}$ & $\begin{array}{l}-4.75^{* * *} \\
(13.66)\end{array}$ \\
\hline CCAR 2017 & $\begin{array}{l}0.74^{* * *} \\
(3.05)\end{array}$ & $\begin{array}{l}0.78^{* * *} \\
(2.90)\end{array}$ & $\begin{array}{l}-1.12^{\star *} \\
(2.50)\end{array}$ & $\begin{array}{l}2.50 \\
(0.87)\end{array}$ & $\begin{array}{l}1.46^{* * *+} \\
(7.24)\end{array}$ & $\begin{array}{l}1.45^{* * *} \\
(4.37)\end{array}$ & $\begin{array}{l}-2.85 \\
(1.42)\end{array}$ & $\begin{array}{l}0.42 \\
(0.26)\end{array}$ \\
\hline CCAR Total & $\begin{array}{l}0.43^{* * *} \\
(2.77) \\
164\end{array}$ & $\begin{array}{l}0.21 \\
(1.24) \\
164\end{array}$ & $\begin{array}{l}0.12^{*} \\
(0.49) \\
74\end{array}$ & $\begin{array}{l}-1.89^{* *} \\
(2.15) \\
74\end{array}$ & $\begin{array}{l}0.35^{\star * *} \\
(2.72) \\
156\end{array}$ & $\begin{array}{l}-0.23 \\
(1.41) \\
156\end{array}$ & $\begin{array}{l}-0.16 \\
(0.35) \\
17\end{array}$ & $\begin{array}{l}-0.95 \\
(1.26) \\
17\end{array}$ \\
\hline EBA 2010 & $\begin{array}{l}1.14^{* * *} \\
(2.72)\end{array}$ & $\begin{array}{l}2.04^{* * *} \\
(2.80)\end{array}$ & & & $\begin{array}{l}0.19 \\
(1.03)\end{array}$ & $\begin{array}{l}0.04 \\
(0.08)\end{array}$ & & \\
\hline EBA 2011 & $\begin{array}{l}0.11 \\
(0.29)\end{array}$ & $\begin{array}{l}0.32 \\
(0.78)\end{array}$ & & & $\begin{array}{l}-0.49^{*} \\
(1.94)\end{array}$ & $\begin{array}{l}-0.91^{* *} \\
(2.15)\end{array}$ & & \\
\hline EBA 2014 & $\begin{array}{l}-0.12 \\
(0.21)\end{array}$ & $\begin{array}{l}-0.12 \\
(0.24)\end{array}$ & $\begin{array}{l}-1.78^{* * *} \\
(2.78)\end{array}$ & $\begin{array}{l}-2.11^{* *} \\
(2.14)\end{array}$ & $\begin{array}{l}0.42 \\
(1.50)\end{array}$ & $\begin{array}{l}-0.17 \\
(0.38)\end{array}$ & $\begin{array}{l}-2.13 \\
(1.01)\end{array}$ & $\begin{array}{l}-2.14 \\
(0.94)\end{array}$ \\
\hline EBA 2016 & $\begin{array}{l}0.11 \\
(0.18) \\
\end{array}$ & $\begin{array}{c}-1.10 \\
(1.50) \\
\end{array}$ & $\begin{array}{l}-0.48 \\
(1.11) \\
\end{array}$ & $\begin{array}{l}-2.05^{\star * *} \\
(4.14)\end{array}$ & $\begin{array}{l}0.08 \\
(0.31) \\
\end{array}$ & $\begin{array}{c}-0.18 \\
(0.31) \\
\end{array}$ & & \\
\hline EBA Total & $\begin{array}{l}0.30 \\
(1.15) \\
171\end{array}$ & $\begin{array}{l}0.37 \\
(1.21) \\
171\end{array}$ & $\begin{array}{l}-1.42^{* *} \\
(3.13) \\
89\end{array}$ & $\begin{array}{l}-2.09^{* * *} \\
(3.45) \\
89\end{array}$ & $\begin{array}{l}0.04 \\
(0.29) \\
170\end{array}$ & $\begin{array}{l}-0.29 \\
(1.15) \\
170\end{array}$ & $\begin{array}{l}-2.13 \\
(1.01) \\
6\end{array}$ & $\begin{array}{l}-2.14 \\
(0.94) \\
6\end{array}$ \\
\hline Total & $\begin{array}{l}0.36^{* *} \\
(2.3) \\
335\end{array}$ & $\begin{array}{l}0.29^{*} \\
(1.65) \\
335\end{array}$ & $\begin{array}{l}-0.72^{* * *} \\
(2.57) \\
163\end{array}$ & $\begin{array}{l}-1.99^{* * *} \\
(3.88) \\
163\end{array}$ & $\begin{array}{l}0.19^{* *} \\
(2.08) \\
326\end{array}$ & $\begin{array}{l}-0.27^{*} \\
(1.71) \\
326\end{array}$ & $\begin{array}{l}-0.67 \\
(1.05) \\
23\end{array}$ & $\begin{array}{l}-1.26 \\
(1.59) \\
23\end{array}$ \\
\hline
\end{tabular}

Table 3 provides results of the empirical impact of the stress test release outcome on banks' equity and CDS performance for tested and non-tested banks.. We estimate average abnormal equity and CDS performance for passing and failing banks according to the description in Section 2.2. $A R$ refers to the abnormal returns computed using a 1-day estimation window. CAR refers to the abnormal returns computed using a 3-day $(-1,+1)$ estimation window. ***, **, and * denotes statistical significance at the $1 \%, 5 \%$, and $10 \%$ level, respectively. All data from the US is taken from the official stress test reports available on the Fed website. All data from Europe is taken from the official stress test reports available on the CEBS and EBA website. We obtain daily perbank equity prices from Reuters Datastream and CDS spreads (5 year-senior) from the S\&P's SNL Financial Database. 
Table 4: Announcement performance summary - tested vs. non-tested

\begin{tabular}{|c|c|c|c|c|c|c|c|c|}
\hline & $\begin{array}{l}\text { Tested } \\
\text { EQ AR }\end{array}$ & EQ CAR & CDS AR & CDS CAR & $\begin{array}{l}\text { Non-Te } \\
\text { EQ AR }\end{array}$ & $\begin{array}{l}\text { ed } \\
\text { EQ CAR }\end{array}$ & CDS AR & CDS CAR \\
\hline CCAR 2012 & $\begin{array}{l}0.23 \\
(1.46)\end{array}$ & $\begin{array}{l}-0.63^{* *} \\
(2.24)\end{array}$ & . & . & $\begin{array}{l}0.04 \\
(0.15)\end{array}$ & $\begin{array}{l}-1.54^{* * *} \\
(3.05)\end{array}$ & . & . \\
\hline CCAR 2013 & $\begin{array}{l}-0.32^{* * *} \\
(3.29)\end{array}$ & $\begin{array}{l}-0.02 \\
(0.09)\end{array}$ & $\begin{array}{l}-1.72^{* *} \\
(2.94)\end{array}$ & $\begin{array}{l}-1.38 \\
(1.26)\end{array}$ & $\begin{array}{l}-0.26 \\
(1.37)\end{array}$ & $\begin{array}{l}-0.37^{*} \\
(1.82)\end{array}$ & $\begin{array}{l}1.37^{*} \\
(2.15)\end{array}$ & $\begin{array}{l}0.34 \\
(0.21)\end{array}$ \\
\hline CCAR 2014 & $\begin{array}{l}-0.96^{* * *} \\
(2.94)\end{array}$ & $\begin{array}{l}-1.75^{* * *} \\
(4.37)\end{array}$ & $\begin{array}{l}-0.13 \\
(0.26)\end{array}$ & $\begin{array}{l}-0.31 \\
(0.46)\end{array}$ & $\begin{array}{l}-0.71^{* * *} \\
(3.32)\end{array}$ & $\begin{array}{l}-1.32^{* * *} \\
(3.36)\end{array}$ & $\begin{array}{c}-0.91 \\
(0.95)\end{array}$ & $\begin{array}{l}-2.32 \\
(1.26)\end{array}$ \\
\hline CCAR 2015 & $\begin{array}{l}-0.34 \\
(1.14)\end{array}$ & $\begin{array}{l}-0.39 \\
(1.11)\end{array}$ & $\begin{array}{l}-1.28^{* *} \\
(2.45)\end{array}$ & $\begin{array}{l}1.24 \\
(1.44)\end{array}$ & $\begin{array}{l}-0.41 \\
(1.65)\end{array}$ & $\begin{array}{l}1.10^{* * *} \\
(4.18)\end{array}$ & $\begin{array}{l}-3.63^{*} \\
(2.64)\end{array}$ & $\begin{array}{l}0.17 \\
(0.09)\end{array}$ \\
\hline CCAR 2016 & $\begin{array}{l}-0.07 \\
(0.61)\end{array}$ & $\begin{array}{l}0.34^{* *} \\
(2.60)\end{array}$ & $\begin{array}{l}0.11 \\
(0.34)\end{array}$ & $\begin{array}{l}1.50^{*} \\
(2.07)\end{array}$ & $\begin{array}{l}0.12 \\
(0.82)\end{array}$ & $\begin{array}{l}0.85^{\text {*** }} \\
(4.32)\end{array}$ & $\begin{array}{l}-0.68 \\
(1.87)\end{array}$ & $\begin{array}{l}0.21 \\
(0.33)\end{array}$ \\
\hline CCAR 2017 & $\begin{array}{l}0.64^{* *} \\
(2.34)\end{array}$ & $\begin{array}{l}0.24 \\
(0.58)\end{array}$ & $\begin{array}{l}-0.91 \\
(1.62)\end{array}$ & $\begin{array}{l}-0.70 \\
(0.77)\end{array}$ & $\begin{array}{l}1.34^{*} \\
(1.78)\end{array}$ & $\begin{array}{l}-0.55 \\
(1.63)\end{array}$ & $\begin{array}{l}-0.50 \\
(5.48)\end{array}$ & $\begin{array}{l}-0.14 \\
(0.04)\end{array}$ \\
\hline CCAR Total & $\begin{array}{l}-0.12 \\
(1.11)\end{array}$ & $\begin{array}{l}-0.34^{* *} \\
(2.29)\end{array}$ & $\begin{array}{l}-0.73^{* * *} \\
(3.13)\end{array}$ & $\begin{array}{l}0.18 \\
(0.45)\end{array}$ & $\begin{array}{l}-0.02 \\
(0.19)\end{array}$ & $\begin{array}{l}-0.42^{* *} \\
(2.53)\end{array}$ & $\begin{array}{l}-0.80 \\
(1.33)\end{array}$ & $\begin{array}{l}-0.40 \\
(0.49)\end{array}$ \\
\hline $\mathrm{N}$ & 163 & 163 & 74 & 74 & 156 & 156 & 17 & \\
\hline EBA 2010 & $\begin{array}{l}0.57 \\
(1.30)\end{array}$ & $\begin{array}{l}0.64 \\
(1.25)\end{array}$ & . & . & $\begin{array}{l}-0.09 \\
(0.24)\end{array}$ & $\begin{array}{l}-0.47 \\
(1.10)\end{array}$ &. & . \\
\hline EBA 2011 & $\begin{array}{l}-1.01^{* * *} \\
(3.76)\end{array}$ & $\begin{array}{l}-1.74^{* * *} \\
(2.70)\end{array}$ & . & . & $\begin{array}{l}-0.41 \\
(1.46)\end{array}$ & $\begin{array}{l}-1.26^{* * *} \\
(3.22)\end{array}$ & . & . \\
\hline EBA 2014 & $\begin{array}{l}0.04 \\
(0.21)\end{array}$ & $\begin{array}{l}0.16 \\
(0.22)\end{array}$ & $\begin{array}{l}1.67^{* * *} \\
(8.90)\end{array}$ & $\begin{array}{l}1.70^{* * *} \\
(3.42)\end{array}$ & $\begin{array}{l}0.28 \\
(0.97)\end{array}$ & $\begin{array}{l}0.30 \\
(0.69)\end{array}$ & $\begin{array}{l}1.91^{* * *} \\
(4.78)\end{array}$ & $\begin{array}{l}2.17^{*} \\
(2.34)\end{array}$ \\
\hline EBA 2016 & $\begin{array}{l}-0.82^{*} \\
(2.04)\end{array}$ & $\begin{array}{l}0.07 \\
(0.13)\end{array}$ & $\begin{array}{l}2.61^{* * *} \\
(8.86)\end{array}$ & $\begin{array}{l}3.14^{* * *} \\
(4.84)\end{array}$ & $\begin{array}{l}1.55^{* *} \\
(2.24)\end{array}$ & $\begin{array}{l}-2.78^{*} \\
(1.99)\end{array}$ & & \\
\hline EBA Total & $\begin{array}{l}-0.24 \\
(1.42) \\
169\end{array}$ & $\begin{array}{l}-0.23 \\
(0.70) \\
169\end{array}$ & $\begin{array}{l}2.07^{* * *} \\
(12.05) \\
86\end{array}$ & $\begin{array}{l}2.32^{* * *} \\
(5.76) \\
85\end{array}$ & $\begin{array}{l}-0.62^{* *} \\
(2.23) \\
169\end{array}$ & $\begin{array}{l}-1.34^{* *} \\
(2.55) \\
169\end{array}$ & $\begin{array}{l}1.91^{* * *} \\
(4.78) \\
6\end{array}$ & $\begin{array}{l}2.17^{*} \\
(2.34) \\
6\end{array}$ \\
\hline Total & $\begin{array}{l}-0.18^{*} \\
(1.79)\end{array}$ & $\begin{array}{l}-0.28 \\
(1.55)\end{array}$ & $\begin{array}{l}0.78^{\star * *} \\
(4.38)\end{array}$ & $\begin{array}{l}1.34^{* * *} \\
(4.53)\end{array}$ & $\begin{array}{l}-0.33^{* *} \\
(2.17)\end{array}$ & $\begin{array}{l}-0.90^{* * *} \\
(3.15)\end{array}$ & $\begin{array}{l}0.09 \\
(0.51)\end{array}$ & $\begin{array}{l}0.27 \\
(0.41)\end{array}$ \\
\hline $\mathrm{N}$ & 332 & 332 & 160 & 159 & 325 & 325 & 23 & 23 \\
\hline
\end{tabular}

Table 4 provides results of the empirical impact of the stress test announcement on banks' equity and CDS performance for tested and non-tested banks.. We estimate average abnormal equity and CDS performance for passing and failing banks according to the description in Section 2.2. $A R$ refers to the abnormal returns computed using a 1-day estimation window. CAR refers to the abnormal returns computed using a 3 -day $(-1,+1)$ estimation window. ${ }^{* *},{ }^{* *}$, and * denotes statistical significance at the $1 \%, 5 \%$, and $10 \%$ level, respectively. All data from the US is taken from the official stress test reports available on the Fed website. All data from Europe is taken from the official stress test reports available on the CEBS and EBA website. We obtain daily perbank equity prices from Reuters Datastream and CDS spreads (5 year-senior) from the S\&P's SNL Financial Database. 
Table 5: Combined performance summary - tested vs. non-tested

\begin{tabular}{|c|c|c|c|c|c|c|c|c|}
\hline & $\begin{array}{l}\text { Tested } \\
\text { EQ AR }\end{array}$ & EQ CAR & CDS AR & CDS CAR & $\begin{array}{l}\text { Non-Te } \\
\text { EQ AR }\end{array}$ & $\begin{array}{l}\text { ed } \\
\text { EQ CAR }\end{array}$ & CDS AR & CDS CAR \\
\hline CCAR 2012 & $\begin{array}{l}0.40 \\
(0.49)\end{array}$ & $\begin{array}{l}-1.42 \\
(1.64)\end{array}$ & . & . & $\begin{array}{l}0.45 \\
(1.11)\end{array}$ & $\begin{array}{l}-2.25^{* * *} \\
(3.11)\end{array}$ & . & . \\
\hline CCAR 2013 & $\begin{array}{l}0.67 \\
(1.47)\end{array}$ & $\begin{array}{l}0.12 \\
(0.23)\end{array}$ & $\begin{array}{l}-1.24 \\
(1.53)\end{array}$ & $\begin{array}{l}-4.74^{* *} \\
(3.15)\end{array}$ & $\begin{array}{l}0.02 \\
(0.07)\end{array}$ & $\begin{array}{l}-0.41 \\
(1.18)\end{array}$ & $\begin{array}{l}0.35 \\
(0.43)\end{array}$ & $\begin{array}{l}0.64 \\
(0.18)\end{array}$ \\
\hline CCAR 2014 & $\begin{array}{l}-1.54^{* * *} \\
(3.94)\end{array}$ & $\begin{array}{l}-2.06^{* * *} \\
(3.58)\end{array}$ & $\begin{array}{l}1.44^{* *} \\
(2.28)\end{array}$ & $\begin{array}{l}1.70 \\
(1.65)\end{array}$ & $\begin{array}{l}-2.22^{* * *} \\
(7.69)\end{array}$ & $\begin{array}{l}-3.20^{* * *} \\
(6.71)\end{array}$ & $\begin{array}{l}-0.29 \\
(0.26)\end{array}$ & $\begin{array}{l}-2.58 \\
(1.46)\end{array}$ \\
\hline CCAR 2015 & $\begin{array}{l}1.12^{* * *} \\
(3.68)\end{array}$ & $\begin{array}{l}-0.48 \\
(1.23)\end{array}$ & $\begin{array}{l}-1.00 \\
(1.28)\end{array}$ & $\begin{array}{l}-1.14 \\
(1.05)\end{array}$ & $\begin{array}{l}0.51^{* *} \\
(2.47)\end{array}$ & $\begin{array}{l}0.25 \\
(0.56)\end{array}$ & $\begin{array}{l}-2.79 * * \\
(3.69)\end{array}$ & $\begin{array}{l}-1.81 \\
(1.44)\end{array}$ \\
\hline CCAR 2016 & $\begin{array}{l}-0.15 \\
(0.34)\end{array}$ & $\begin{array}{l}1.25^{* *} \\
(2.71)\end{array}$ & $\begin{array}{l}-0.06 \\
(0.08)\end{array}$ & $\begin{array}{l}-6.61^{* * *} \\
(3.67)\end{array}$ & $\begin{array}{l}0.79^{* *} \\
(2.53)\end{array}$ & $\begin{array}{l}1.91^{* * *} \\
(4.87)\end{array}$ & $\begin{array}{l}0.41 \\
(0.17)\end{array}$ & $\begin{array}{l}-4.54 \\
(4.65)\end{array}$ \\
\hline CCAR 2017 & $\begin{array}{l}1.38^{* * *} \\
(3.56)\end{array}$ & $\begin{array}{l}1.02^{* *} \\
(2.20)\end{array}$ & $\begin{array}{l}-2.03^{* *} \\
(2.80)\end{array}$ & $\begin{array}{l}1.80 \\
(0.56)\end{array}$ & $\begin{array}{l}2.79^{*} \\
(1.79)\end{array}$ & $\begin{array}{l}0.89^{* *} \\
(2.24)\end{array}$ & $\begin{array}{l}-3.35 \\
(1.82)\end{array}$ & $\begin{array}{l}0.28 \\
(0.18)\end{array}$ \\
\hline $\begin{array}{l}\text { CCAR Total } \\
\mathrm{N}\end{array}$ & $\begin{array}{l}0.31 \\
(1.58) \\
163\end{array}$ & $\begin{array}{l}-0.13 \\
(0.61) \\
163\end{array}$ & $\begin{array}{l}-0.61^{*} \\
(1.69) \\
74\end{array}$ & $\begin{array}{l}-1.70^{*} \\
(1.74) \\
73\end{array}$ & $\begin{array}{l}0.33^{*} \\
(1.94) \\
156\end{array}$ & $\begin{array}{l}-0.65^{* *} \\
(2.60) \\
156\end{array}$ & $\begin{array}{l}-0.96 \\
(1.66) \\
17\end{array}$ & $\begin{array}{l}-1.34 \\
(1.18) \\
17\end{array}$ \\
\hline EBA 2010 & $\begin{array}{l}1.71^{* * *} \\
(2.84)\end{array}$ & $\begin{array}{l}2.68^{\star * *} \\
(2.98)\end{array}$ & 1 & r & $\begin{array}{l}0.09 \\
(0.25)\end{array}$ & $\begin{array}{l}-0.43 \\
(0.74)\end{array}$ & . & . \\
\hline EBA 2011 & $\begin{array}{l}-0.89^{*} \\
(1.88)\end{array}$ & $\begin{array}{l}-1.42^{*} \\
(1.91)\end{array}$ & . & . & $\begin{array}{l}-0.90^{* *} \\
(2.30)\end{array}$ & $\begin{array}{l}-2.17^{* * *} \\
(3.74)\end{array}$ & . & . \\
\hline EBA 2014 & $\begin{array}{l}-0.08 \\
(0.16)\end{array}$ & $\begin{array}{l}0.03 \\
(0.01)\end{array}$ & $\begin{array}{l}-0.11 \\
(0.17)\end{array}$ & $\begin{array}{l}0.12 \\
(0.11)\end{array}$ & $\begin{array}{l}0.73^{*} \\
(1.80)\end{array}$ & $\begin{array}{l}0.13 \\
(0.43)\end{array}$ & $\begin{array}{l}-0.22 \\
(0.10)\end{array}$ & $\begin{array}{l}0.03 \\
(0.01)\end{array}$ \\
\hline EBA 2016 & $\begin{array}{l}-0.71 \\
(0.89)\end{array}$ & $\begin{array}{l}-1.03 \\
(1.16)\end{array}$ & $\begin{array}{l}2.13^{* * *} \\
(3.39)\end{array}$ & $\begin{array}{l}1.05 \\
(1.22)\end{array}$ & $\begin{array}{l}-1.63^{*} \\
(1.93)\end{array}$ & $\begin{array}{l}-3.00^{*} \\
(1.98)\end{array}$ & & \\
\hline EBA Total & $\begin{array}{l}0.06 \\
(0.19) \\
169\end{array}$ & $\begin{array}{l}0.14 \\
(0.30) \\
169\end{array}$ & $\begin{array}{l}0.65 \\
(1.64) \\
86\end{array}$ & $\begin{array}{l}0.23 \\
(0.77) \\
85\end{array}$ & $\begin{array}{l}-0.58^{*} \\
(1.84) \\
168\end{array}$ & $\begin{array}{l}-1.62^{* * *} \\
(2.77) \\
168\end{array}$ & $\begin{array}{l}-0.22 \\
(0.10) \\
6\end{array}$ & $\begin{array}{l}0.03 \\
(0.01) \\
6\end{array}$ \\
\hline Total & $\begin{array}{l}0.18 \\
(0.99) \\
332\end{array}$ & $\begin{array}{l}0.01 \\
(0.00) \\
332\end{array}$ & $\begin{array}{l}0.06 \\
(0.52) \\
160\end{array}$ & $\begin{array}{l}-0.66 \\
(0.85) \\
158\end{array}$ & $\begin{array}{l}-0.14 \\
(0.77) \\
324\end{array}$ & $\begin{array}{l}-1.16^{\star \star *} \\
(3.53) \\
324\end{array}$ & $\begin{array}{l}-0.57 \\
(1.16) \\
23\end{array}$ & $\begin{array}{l}-0.99 \\
(0.99) \\
23\end{array}$ \\
\hline
\end{tabular}

Table 5 provides results of the empirical impact of the joint stress test release event and announcement on banks' equity and CDS performance for tested and non-tested banks.. We estimate average abnormal equity and CDS performance for passing and failing banks according to the description in Section 2.2. AR refers to the abnormal returns computed using a 1-day estimation window. CAR refers to the abnormal returns computed using a 3-day $(-1,+1)$ estimation window. ${ }^{* * *}, * *$, and $*$ denotes statistical significance at the $1 \%, 5 \%$, and $10 \%$ level, respectively. All data from the US is taken from the official stress test reports available on the Fed website. All data from Europe is taken from the official stress test reports available on the CEBS and EBA website. We obtain daily per-bank equity prices from Reuters Datastream and CDS spreads (5 year-senior) from the S\&P's SNL Financial Database. 
Table 6: Bank fundamentals and stress test outcomes

\begin{tabular}{l|l|ll}
\hline \hline MODEL & \multicolumn{1}{|c|}{$(\mathbf{1})$} & \multicolumn{1}{c}{$(\mathbf{2})$} & \multicolumn{1}{c}{$(\mathbf{3})$} \\
\hline Sample & EQ Event Study & EQ Event Study & CDS Event Study \\
Regression approach & Logistic (Odds ratio) & OLS & OLS \\
Dependent variable & PASS=1 & EQ AR & CDS AR \\
\hline EXCESS CAP & 14.452 & $0.267^{* *}$ & 0.098 \\
& $(1.51)$ & $(2.50)$ & $(0.34)$ \\
ASSET QUALITY & $0.956^{* *}$ & $-0.005^{*}$ & 0.001 \\
& $(2.15)$ & $(1.92)$ & $(0.10)$ \\
LEVERAGE & 0.123 & $-0.507^{* *}$ & 0.354 \\
& $(1.07)$ & $(2.19)$ & $(0.50)$ \\
RWA/A & 1.118 & $-0.083^{* * *}$ & 0.058 \\
& $(0.67)$ & $(3.10)$ & $(0.37)$ \\
ROAE & 1.049 & 0.002 & -0.012 \\
Announcement AR & $(1.21)$ & $(0.14)$ & $(0.12)$ \\
& $3.076^{* *}$ & 0.054 & 0.058 \\
Constant & $(1.96)$ & $(1.16)$ & $(0.37)$ \\
& & & \\
Stress Test - Year FE & 1533.895 & -1.734 & -3.350 \\
\hline $\mathbf{N}$ & $(1.11)$ & $(1.32)$ & $(0.74)$ \\
R-squared & & Yes & Yes \\
\hline \hline
\end{tabular}

Table 6 provides results of different regression models that seek to predict the outcome of a bank's stress test with corresponding performance at the release day. Specification (1) reports the results of a logistic regression to assess the predictive power of the above-mentioned bank characteristics (EXCESS CAP, ASSET QUALITY, LEVERAGE, RWA/A, ROAE, ANNOUNCEMENT $A R$ ) on the binary pass / fail stress test outcome of a bank. In specification (2) we then run an OLS regression (with stress test and year fixed effects) to predict the abnormal equity- and CDS performance of banks at the stress test release using the same independent variables. In specification (3) we repeat the investigation of regression model (2), but use abnormal CDS performance as the dependent variable. ${ }^{* * *}, * *$, and * denotes statistical significance at the $1 \%, 5 \%$, and $10 \%$ level, respectively. All data from the US is taken from the official stress test reports available on the Fed website. All data from Europe is taken from the official stress test reports available on the CEBS and EBA website. We obtain daily per-bank equity prices from Reuters Datastream and CDS spreads (5 year-senior) from the S\&P's SNL Financial Database. 